\title{
Upper Cretaceous lithostratigraphy of the Panagyurishte strip (Central Bulgaria) - part of the Late Cretaceous Apuseni-Banat- Timok-Srednogorie magmatic belt
}

\author{
Dian Vangelov, Ianko Gerdjikov, Docho Dochev, Zornitsa Dotseva, Stefan Velev, \\ Yasen Dinev, Diliana Trayanova, Jenny Dancheva
}

Sofia University “St Kliment Ohridski”, 15 Tsar Osvoboditel Blvd, 1504 Sofia, Bulgaria;

e-mails:dedo@gea.uni-sofia.bg; janko@gea.uni-sofia.bg;dochev@gea.uni-sofia.bg; zdoceva@gea.uni-sofia.bg; velev@polar.uni-sofia.bg; yasendinev@abv.bg; dilqna.traqnova@gmail.com; jendan378@gmail.com

(Accepted in revised form: November 2019)

\begin{abstract}
The investigations of the Upper Cretaceous Panagyurishte and Chelopech volcano-sedimentary strips of the Central Srednogorie tectonic subzone date back to the end of $19^{\text {th }}$ and became more intensive during the middle of the $20^{\text {th }}$ century, mainly due to the discovery of important mineral deposits in the area. Our field work during the last 15 years and analysis of previously published data show that the existing lithostratigraphic scheme does not cover the entire spectrum of lithologies, successions and interrelations in both strips. This study deals with four stratigraphic sections, along the valleys of the Topolnitsa, Kamenitsa and Mirkovska rivers, and their correlation on the basis of the Turonian/Coniacian boundary, local extinction event and palaeontological data that demonstrate the unreliability of already existing schemes. The previously used "layer-cake" stratigraphic model does not reflect the diachronism of the studied units or the existence of subaerial volcano craters, together with synchronous deposits. In this paper, we also propose a subdivision of the intervals containing magmatic and sedimentary rocks into individual members, including non-layered magmatic centres, stratified lava flow and volcanoclastic flow deposits and stratified epiclastic deposits of mainly turbiditic origin, instead of the currently used Chelopech Formation. The presented herein new data do not cover entirely the wide palette of problems with the lithostratigraphy of the area, but clearly demonstrate the necessity of its revision, especially for practical application and better understanding of the Late Cretaceous evolution of the area.
\end{abstract}

Vangelov, D., Gerdjikov, I., Dochev, D., Dotseva, Z., Velev, S., Dinev, Y., Trayanova, D., Dancheva, J. 2019. Upper Cretaceous lithostratigraphy of the Panagyurishte strip (Central Bulgaria) - part of the Late Cretaceous Apuseni-Banat-Timok-Srednogorie magmatic belt. Geologica Balcanica 48 (3), 11-33.

Keywords: Upper Cretaceous, Panagyurishte strip, lithostratigraphy, Srednogorie Zone.

\section{INTRODUCTION}

The general problem when working in magmaticsedimentary sequences is the erection of a reliable lithostratigraphic scheme, depicting the time of the magmatic processes and their relationship with the synchronous epiclastic and sedimentary rocks. Additionally, the syn-depositional and syn-magmatic tectonics, size/dimensions of the basin, basin system or magmatic belt and post-depositional tectonics create obstacles for correlation between differ- ent parts of the sequences and adjacent areas. The Upper Cretaceous Panagyurishte and Chelopech strips of the Central Srednogorie tectonic subzone are a good example of how one lithostratigraphic scheme, suggested 40 years ago for a small area and applied for the surrounding terrains, does not reflect the results of more detailed investigations, especially related to mineral deposit prospection and exploration.

The Upper Cretaceous sequence in the Panagyurishte and Chelopech strips of the Central Sredno- 
gorie tectonic subzone is a part of the peri-Tethyan arc/back-arc basin system of the Apuseni-BanatTimok-Srednogorie magmatic and metalogenic belt (Gallhofer et al., 2015, and references therein) (Fig. 1). Although sharing some similarities, such as intermediate magmatism and globally spread CORB (Cretaceous Ocean Red Beds, Wang et al., 2009), the Upper Cretaceous succession represents some specific features in every subbasin. One of the reasons is the geological composition and evolution of the basement, intensively affected by the Early Alpine deformation phase. The basin system evolution, Late Alpine orogeny and post-orogenic extension additionally complicated the correlation of the Upper Cretaceous basin-fill remnants.
The existing lithostratigraphic scheme for both strips does not cover the entire spectrum of lithological successions and their interrelations (Fig. 2). According to our new field data, the previously established lithostratigraphic units cannot be correlated even in short distances due to rapid changes in their lithology, facies, colour and thickness. The problems in this scheme are connected with: i) the lowermost part of the succession; ii) the part containing magmatic rocks; and iii) the uppermost intervals of the succession. The lowermost part of the succession comprises variable lithologies, from terrestrial conglomerates to relatively deeper-water marlstones and micrite limestones, with lateral interfingering. They are not stratified and it will be

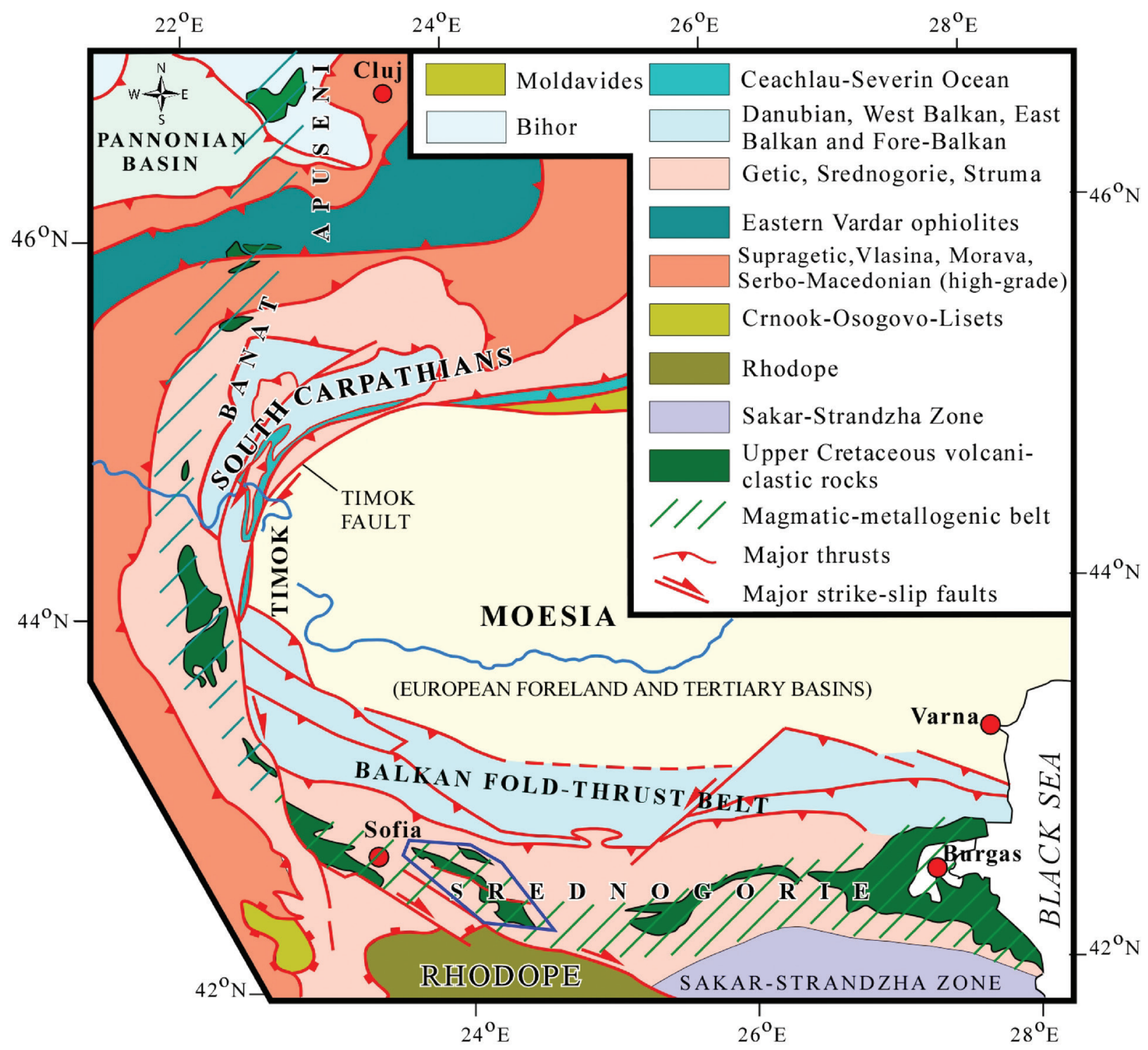

Fig. 1. Regional sketch map of the Apuseni-Banat-Timok-Srednogorie magmatic and metalogenic belt (modified after Knaak et al., 2016). 


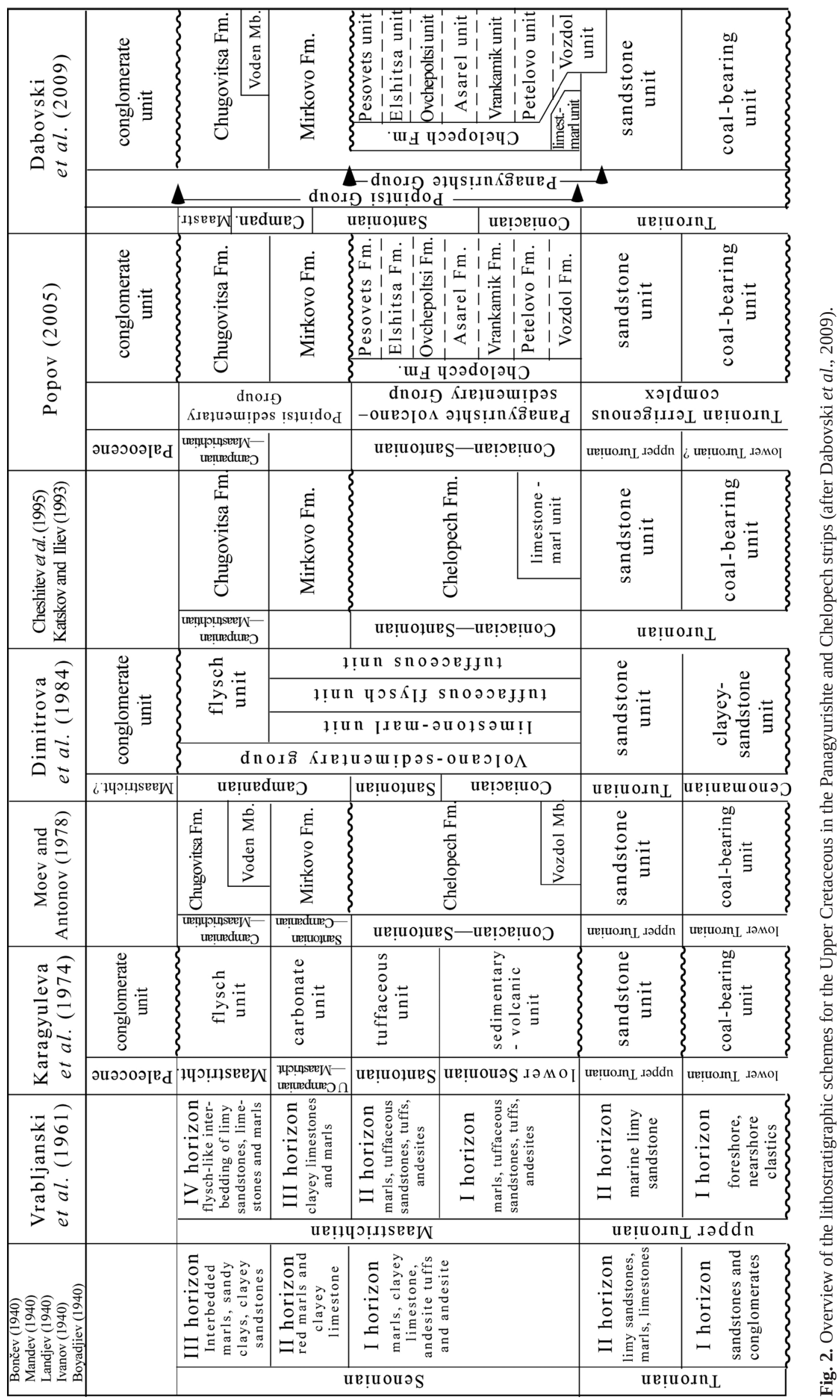


better, for practical reasons, to be included into one basal terrigenous unit.

A common problem for volcano-sedimentary terrains, especially those with subaerial volcanic activity, is the transition from volcanic derivates into subaqueous epiclastic volcanic sediments and their interrelation with the background deposits. This complicates the facies and depositional systems distribution, as well as their migration, and finally their interpretation. On the basis of our studies in the Panagyurishte and the Chelopech strips, a critical overview of the existing data is presented.

Also, on the basis of detailed field observations and numerous previously published magmatic rock ages, we suggest a revision of the Upper Cretaceous lithostratigraphic scheme. Another reason for the revision is that some of the biggest mineral deposits in Bulgaria are located in the area, and therefore a more reliable stratigraphic scheme will be useful for better understanding the geological evolution, thus providing updated knowledge for future prospective activities.

Bončev (1940), who presented the first complete overview of the stratigraphy and tectonics of the western part of the Panagyurishte strip, suggested that the Upper Cretaceous sequence cropping out along the Topolnitsa River is less deformed and, therefore, most suitable for better understanding the lithological successions. Following this suggestion, and based on more than 15 years of field work experience in the area, we present here four representative stratigraphic sections, which illustrate the dynamic of the depositional systems and the magmatic events, and which will also be useful for future correlations of the Upper Cretaceous successions in the Central Srednogorie subzone. The correlations between the sections were made on the basis of similar lithological successions, the position of the Turonian/Coniacian boundary, and one local extinction event. The preliminary palaeontological investigations and summarized published information could allow fixing other important chronostratigraphic boundaries (i.e., Santonian/Campanian and Campanian/Maastrichtian), which eventually will help to correlate the lithological successions. For both the Panagyurishte and Chelopech strips, the lithostratigraphic scheme of Moev and Antonov (1978) was taken into account.

\section{GEOLOGICAL SETTING}

The Srednogorie Zone represents a chain of en echelon strike-slip and pull-apart basins, developed in dextral transtenssional tectonics upon the fragments of the Early Alpine orogen (Ivanov, 1998, 2017). This mechanism of basin formation commonly results in a very rapid change of lithologies, facies migration and deposition in local depocentres formed during the initial stages of basin evolution.

The Upper Cretaceous sedimentary successions in the western part of the Central Srednogorie tectonic subzone crop out in the so called Chelopech and Panagyurishte strips (Fig. 3). As a whole, both strips show similar composition: basal siliciclastic sediments, an interval including magmatic rocks, followed by a volcaniclastic and epiclastic deposits, covered by regionally developed in peri-Tethyan realm facies white, red and green limestones, with fast transition to sandy low-density turbidites. The crystalline basement of the Srednogorie Zone consists of Cadomian and Palaeozoic high-grade metamorphic rocks intruded by different in age granitoids (Iliev and Katskov, 1990; Velichkova et al., 2004), whereas, in the southern slopes of the Stara Planina Mountain (along the northern rim of the Chelopech strip), mostly lower Palaeozoic low-grade metasediments are exposed. Permian and Triassic clastic and carbonate rocks are locally preserved in both strips (Antonov et al., 2010a). In the western part of the Panagyurishte strip, Carboniferous, Permian, Triassic and Jurassic rocks (Tzankov, 1961; Iliev and Katskov, 1990) are also part of the pre-Upper Cretaceous basement (Fig. 3). The heterogeneity of the basement lithologies is a result of the intensive Early Alpine orogeny, during which different levels of exhumation and erosion were achieved, the most prominent being those in the Central Srednogorie tectonic subzone.

The Panagyurishte strip (Bončev, 1940) is more than $80 \mathrm{~km}$ long, $10-12 \mathrm{~km}$ wide, and is characterized by variable and laterally changing lithologies of Turonian-Maastrichtian (Palaeocene?) age. Historically, the basin fill was referred to as Turonian (e.g., Dimitrov, 1936; Bončev, 1940; Nikolaev, 1947) coal-bearing and sandstone units (Moev and Antonov, 1978) or limestone-marl unit (Vrâbljanski et al., 1961; Dimitrova et al., 1984). The basal clastic part of the sequence is generally very thin (up to 100 -m thick in the central part, along the Topolnitsa, Kamenitsa and Mirkovo rivers, or even missing in the eastern part of the strip, dominated by clayey-limestone sequence in the western part, around Makotsevo and Gorna Malina villages. This part is also very thin and clastic/clayey in the westernmost part of the strip, north of Eleshnitsa Village (Fig. 3). The magmatic rocks are irregularly distributed and correspond to non-layered magmatic/volcanic centres (some of them subaerial) or stratified lava, volcaniclastic or epiclastic flow deposits, all of them 


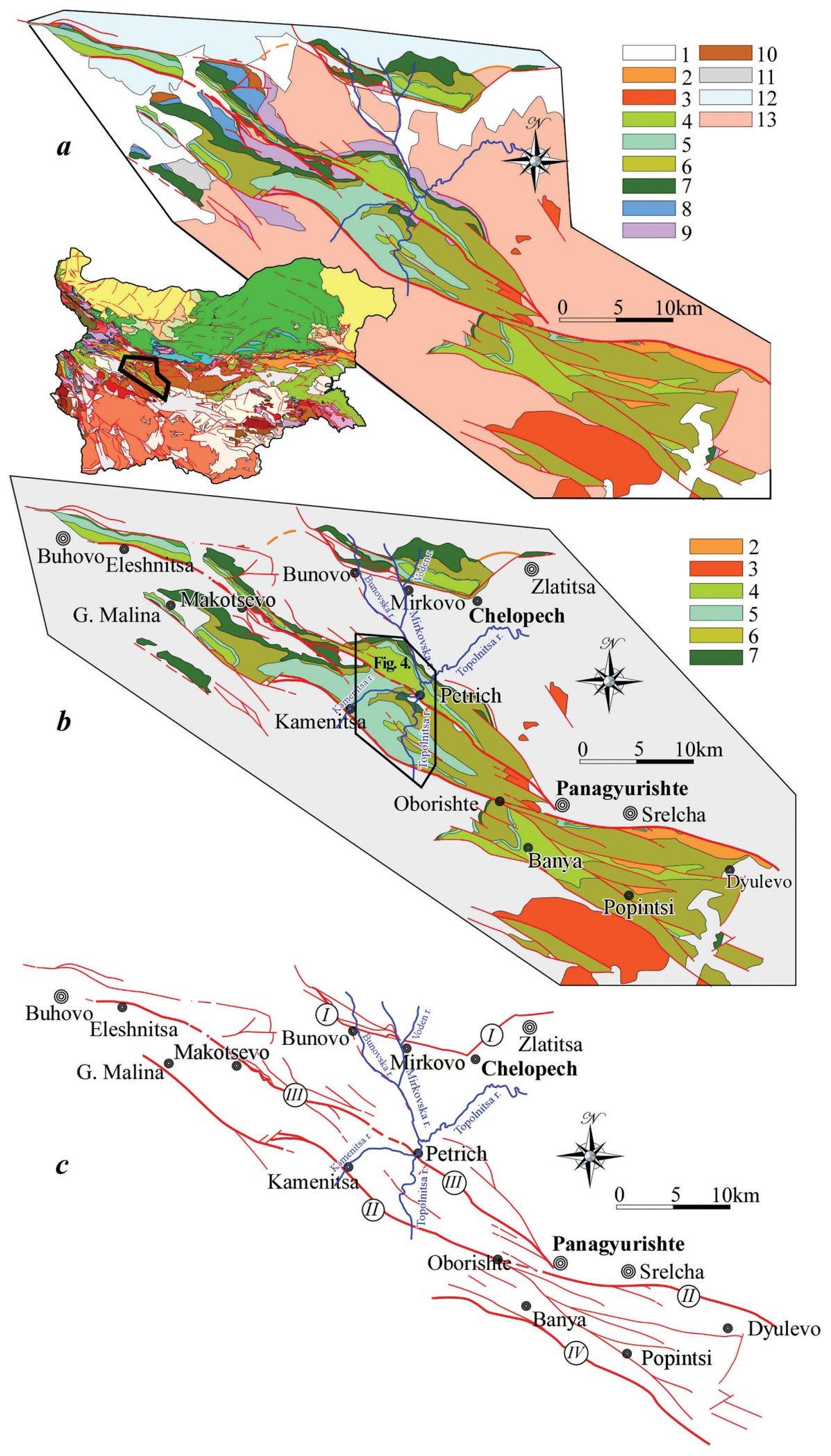

Fig. 3. Geological sketch map of the studied area (modified from Iliev and Katskov, 1990, and Antonov et al., 2010, and including our data): (a) the Upper Cretaceous in the Panagyurishte and Chelopech strips and their underlying rocks: 1 - Neogene-Quaternary; 2 - Palaeocene; 3 - Upper Cretaceous plutons; 4 - Chugovitsa Formation; 5 - Mirkovo Formation; 6 - volcano-terrigenous complex; 7 - basal terrigenous unit; 8 - Jurassic; 9 - Triassic; 10 - Permian; 11 - Upper Carboniferous; 12 - Palaeozoic low-grade metamorphites; 13 - Palaeozoic high-grade metamorphites; (b) geological sketch map of the Upper Cretaceous rocks in the Panagyurishte and Chelopech strips; (c) sketch map of the Late Alpine fault system affecting the Upper Cretaceous rocks: $I$ - BunovoAnton fault zone; II - Rakovitsa-Kamenitsa and Panagyurishte faults; III - Negushevo-Petrich fault; IV - Stefanchovski fault. 
included previously in the Chelopech Formation (Moev and Antonov, 1978). Up-section, epiclastic turbidites (previously attributed to the Chelopech Formation) occur, as well as the red limestones of the Mirkovo Formation and the sandy turbidites of the Chugovitsa Formation, all showing variable lateral changes and intercalations. Still poorly dated as Palaeocene, coarse-grained siliciclastic sediments occur only in the easternmost part of the strip (Karagyuleva et al., 1974; Zagorchev et al., 2001).

The Chelopech strip (15 km long and 2-4 km wide) is built of a Turonian-Maastrichtian succession with a basal sandstone unit, locally represented by packages of red terrestrial conglomerates at the very base, a prominent magmatic centre north of Chelopech Village (Chelopech Formation), the Mirkovo Formation and the Chugovitsa Formation, which lies on the top. The western part of the strip is characterized by variable lithologies, ranging from claystones to conglomerates in the basal part, lack of magmatic rocks, and fewer, thinner epiclastic intervals.

The similarity between the sequences in the Panagyurishte and Chelopech strips, as well as the comparatively good fit in the ages of the distinguished sub-units, could be an indication for the existence of either a single Cretaceous basin or a connected basin system, strongly disrupted at later times by Tertiary tectonics. Both strips are strongly, yet unevenly, affected by the Late Alpine compression.

The Panagyurishte strip is crosscut obliquely by a more than $70 \mathrm{~km}$ long fault, named west of Panagyurishte as Kamenitsa-Rakovitsa fault and east of Panagyurishte as Panagyurishte fault. Ivanov (2017) was the first to suggest that they represent a single structure with criteria for combined compressional and dextral sense of shearing (Fig. 3). From the town of Panagyurishte to Petrich Village, and most probably westward to Eleshnitsa Village, another dextral transpressional fault can be traced, along which the pre-Cretaceous basement was uplifted in its hanging wall. The style of deformation is very heterogeneous, with more intensively deformed eastern part, where mainly the Upper Cretaceous rocks are affected. The middle part, along the Topolnitsa River, is fold-dominated, whereas intensive deformation, involving the basement uplift, affected mostly the western part of the strip.

Along the southern margin of the Chelopech strip, the Bunovo-Anton compressional zone was traced (Dotseva et al., 2016), and it emplaced the Variscan basement onto the Upper Cretaceous succession. The entire volume of the Chelopech strip is deformed in varying degrees, with larger shorten- ing, along the southern margin of the strip, as well as the whole western part (Fig. 3). The entire area is affected by post-Eocene to present day's extensional tectonics related to several kilometres of exhumation (Kounov et al., 2017).

\section{Lithostratigraphic characteristics of the Upper Cretaceous succession in the central part of the Panagyurishte strip}

The Upper Cretaceous rocks in the central part of the Panagyurishte strip are very well exposed and less deformed than the surrounding areas, and therefore allow detailed description of the entire succession. For the last 17 years, this area has been subjected to extensive mapping in scale 1:10 000 by our team, which confirms the need for lithostratigraphic revision (Fig. 4). Herein, the Upper Cretaceous successions are described in four representative sections/areas and an attempt for their correlation is made (Fig. 5). These successions are key-sections for tracing the lateral variations of the lithologies/ units in other parts of both the Panagyurishte and Chelopech strips. In all sections, the observed lithologies are in superposition, but the correlation between them is hindered by the changes in lithology, thickness, age and other characteristics in very short distances. From the south to the north, the studied sections are: section Topolnitsa-South, section Kamenitsa River, section Topolnitsa-North and section Mirkovska River.

\section{Section Topolnitsa-South}

South of Petrich Village, along the western bank of the Topolnitsa River, the Upper Cretaceous succession is represented by variable lithologies, spanning the Turonian to the Maastrichtian (Fig. 5). The basal part (package 1) is composed of $5-m$ thick, yellowish conglomerates and sandstones that overly the Upper Triassic quartz-arenites (Fig. $6 a-c$ ). These rocks show signs of redeposition (e.g., hummocky cross stratification, rip-up clast, channel-fill conglomerate, escape burrows) and were probably generated by storm events. This package is covered, with a sharp boundary, by reddish massive ( 10-15-m thick) pebble to cobble conglomerates (package 2), which are irregularly intercalated with shale layers. The clasts of the conglomerates consist predominantly of Middle Triassic dolostones, rarely Upper Triassic quartz-arenites and Palaeozoic high-grade metamorphites and granitoids (Fig. 6d). These rocks most likely represent alluvial-fed. Above them, grey lens-shaped conglomerates and sandstones, with rare volcanic clasts 


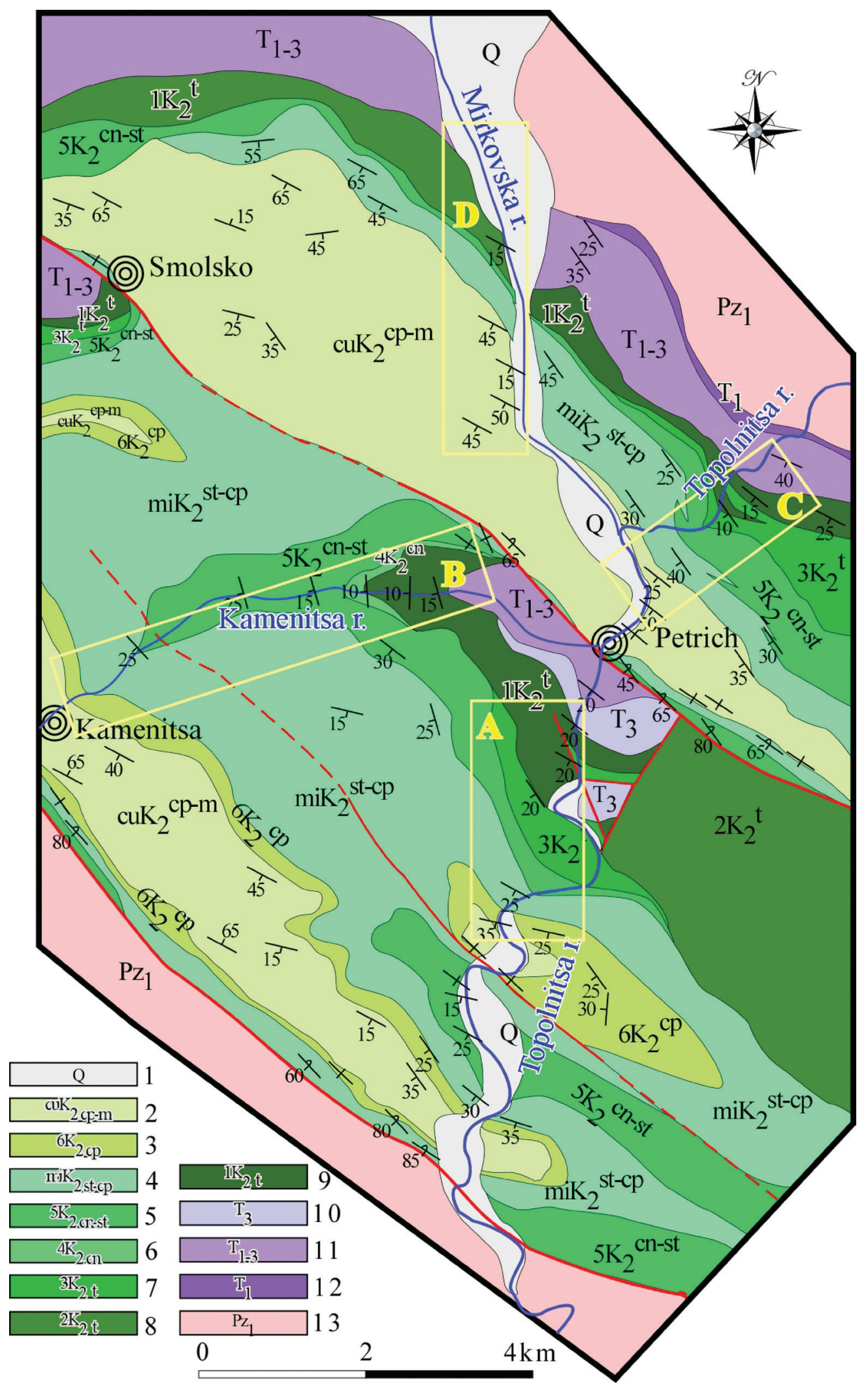

Fig. 4. Geological sketch map of the area of Petrich Village with locations the studied sections: $A$ - Topolnitsa-South; $B$ - Ka-

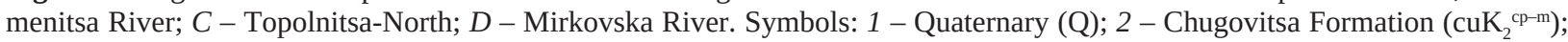
3 - upper epiclastic unit $\left(6 \mathrm{~K}_{2}{ }^{\mathrm{cp}}\right) ; 4$ - Mirkovo Formation ( $\left.\mathrm{miK}_{2}^{\mathrm{st}-\mathrm{cp}}\right) ; 5$ - lower epiclastic unit $\left(5 \mathrm{~K}_{2}^{\mathrm{cn}-\mathrm{st}}\right) ; 6$ - marl-limestone unit $\left(4 \mathrm{~K}_{2}^{\mathrm{cn}}\right) ; 7$ - volcaniclastic units $\left(3 \mathrm{~K}_{2}^{\mathrm{t}}\right) ; 8$ - Vran Kamak magmatic center $\left(2 \mathrm{~K}_{2}^{\mathrm{t}}\right) ; 9$ - basal terrigenous unit $\left(1 \mathrm{~K}_{2}^{\mathrm{t}}\right) ; 10-\mathrm{Moesian}$ Terrigenous-Carbonate Group ( $\left.\mathrm{T}_{3}\right) ; 11$ - Iskar Carbonate Group $\left(\mathrm{T}_{1-3}\right) ; 12$ - Petrohan Terrigenous Group $\left(\mathrm{T}_{1}\right) ; 13$ - Palaeozoic high-grade metamorphites $\left(\mathrm{Pz}_{1}\right)$. 


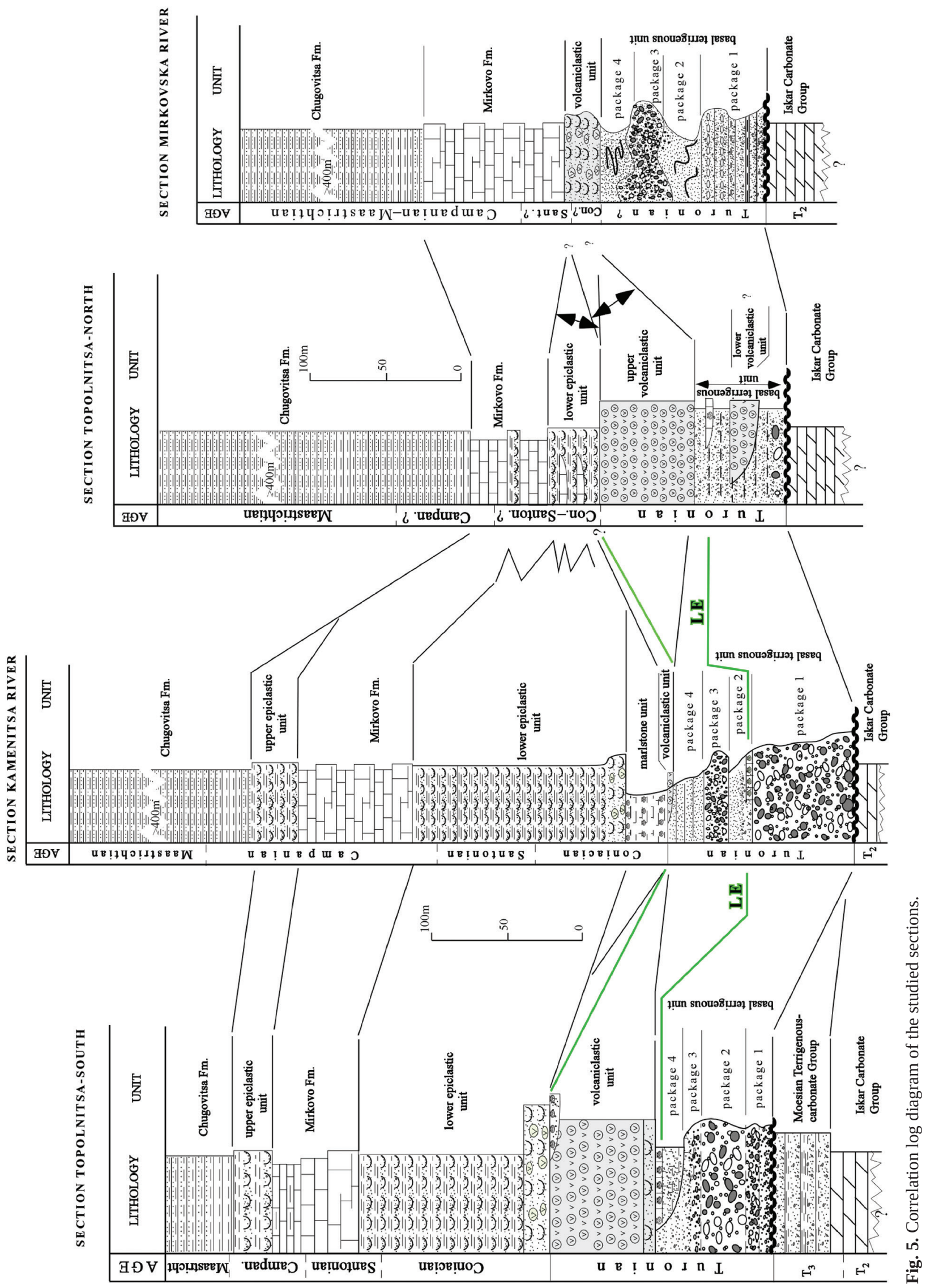



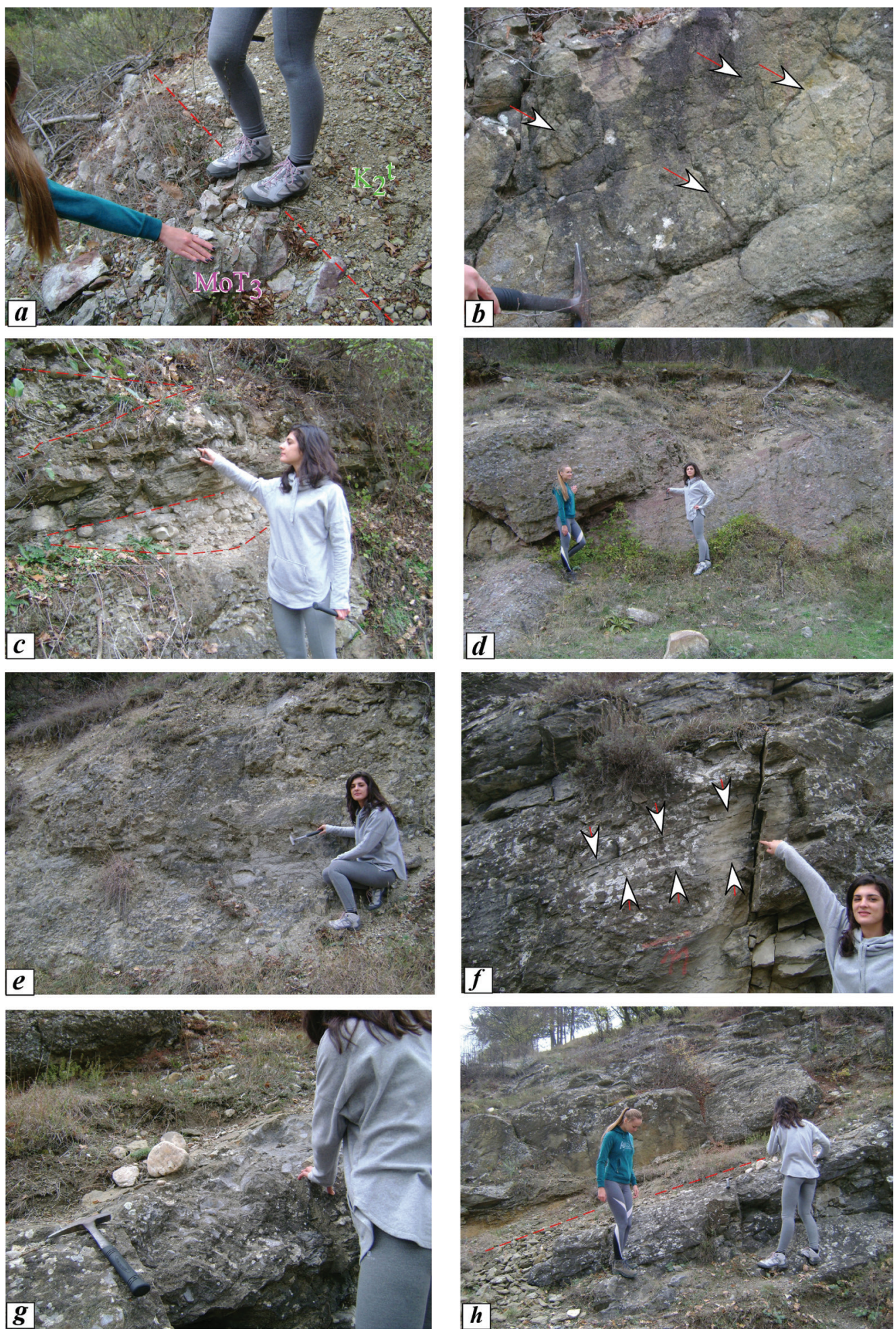

Fig. 6. Field views from section Topolnitsa-South: $a$ ) the paraconformity between the Upper Triassic quartz-arenites (Moesian Carbonate-Terrigenous Group) and the Turonian conglomerate-sandstone couplets (basal terrigenous unit); $b, c$ ) sedimentary structures (conglomerate-sandstone rhythms, inverse to normal grading, parallel and hummocky cross bedding, traction carpets, escaping burrows, channelized conglomerates) indicating a deposition controlled by storm events (tempestites) at the basal part of the Upper Cretaceous succession; $d$ ) package 2 above $b$ and $c$ is composed of thick-bedded to massive red alluvial-fed terrestrial conglomerates with rare shale, parallelly bedded layers; $e$ ) package 3 of the basal terrigenous unit is represented by grey to bluish clast- to matrix-supported conglomerates (sandy debrites) containing clasts of volcanic rocks and irregularly distributed epiclastic material in the matrix; $f$ ) locally developed medium-scale hummocky cross-bedding above package 4, indicating storm event influence (white arrows); $g$ ) shell bed containing abundant fossils (bivalves, ammonites and brachiopods), interpreted as evidence for local extinction event; $h$ ) sharp boundary between the basal terrigenous unit and the epiclastic gravely sandstones. 
and epiclastic matrix occur (package 3, see Fig. 6e). Up-section, with a fast transition follow 10-15-m thick micaceous-calcareous sandstones (package 4) with concretions and irregular lenses of limestones, rare bivalve shells and medium-scale hummocky cross stratification (Fig. 6f). These sandstones gradually pass into thick-bedded sandy limestones in the topmost part of the package and can be traced laterally only for about $1.5 \mathrm{~km}$. The capped limestone bed contains abundant bivalves of the genus Exogyra, as well as brachiopods and ammonites, indicating local extinction event. It is covered, with a sharp boundary, by epiclastic sandstone with traces of hydrothermal activity (Fig. $6 g, h$ ). We refer the lowermost part of the Upper Cretaceous succession (packages 1-4) as basal terrigenous unit. The magmatic and epiclastic rocks in the existing geological maps of the Panagyurishte strip are marked as the Chelopech Formation, which displays the most remarkable lateral and vertical variations in relation to the emplacement of the volcanic centres. Thus, no single section can give representative information about the distribution of the lithologies and their interrelations. Following this, the presented below description refers not only to the stratigraphic section along the western bank of the Topolnitsa River, but also includes a wider area to the south and southeast of Petrich Village.

The section along the western bank of the Topolnitsa River continues with volcaniclastic and epiclastic flow deposits, overlying, with a sharp boundary, the basal terrigenous unit (Figs 6h, 7a, b). Georgiev et al. (2013) reported the transition from subaerial to submarine palaeoenvironment and the changeable thickness of this package (35-60 m). Above it follows a 120-m thick succession of thin- to medium-bedded epiclastic turbidites with rare lenses of epiclastic debrites. We consider these epiclastic turbidites as a part of an independent informal lithostratigraphic unit: lower epiclastic unit, which, however, needs to be further investigated in detail.

The base of the unit is herein considered to coincide with the Turonian/Coniacian boundary ( 89.7 Ma) (Fig. 7c-f). The base of the Coniacian is defined by the first occurrence of the inoceramid bivalve Cremnoceramus deformis erectus (Meek, 1876), a cladogenetic successor of the Cremnoceramus waltersdorfensis lineage (Walaszczyk et al., 2010). The first occurrence of Cremnoceramus deformis erectus (Meek, 1876) (Fig. 7d) was detected in thin-bedded, red limestones at the base of the unit (Fig. 7c). This taxon is accompanied by Cremnoceramus? bicorrugatus bicorrugatus (Marwick, 1926) and Inoceramus lusatiae (Andert, 1911). The lower-middle parts of the lower Coniacian (Crem- noceramus waltersdorfensis hannovrensis Zone) is indicated in grey limestones, lying $3 \mathrm{~m}$ above the boundary interval, by the following species: Cremnoceramus deformis erectus (Meek, 1876), C. waltersdorfensis hannovrensis (Heinz, 1932), C. denselamellatus (Kotsyubinsky, 1965), Inoceramus vistulensis (Walaszczyk, 1992) and Inoceramus cf. anulatus (Goldfuss, 1836). With a fast transition, the lower epiclastic unit is overlain by the limestones of the Mirkovo Formation, which is represented by three superpositioned packages with different characteristics: $i$ ) thick-bedded to massive interlayered white and red limestones with characteristics of carbonate muddy turbidites and crenulation cleavage (Fig. 8a); ii) medium- to thick-bedded white limestones representing amalgamated carbonate turbidites (Fig. 8b); and iii) thin-bedded white carbonate turbidites (Fig. 8c). The formation's total thickness in this location is about $45-50 \mathrm{~m}$.

The 12-15-m thick sequence overlying the Mirkovo Formation is composed of thin- to thick-bedded, epiclastic sandy to muddy turbidites, which cannot be included in either the Mirkovo or the Chugovitsa formations due to the contrasting lithology (Fig. $8 d, e$ ). This package is traced for more than $12 \mathrm{~km}$ between the valleys of the Topolnitsa and Kamenitsa rivers and meets all requirements to be formalized as a separate lithostratigraphic unit. Despite that, we describe this succession informally as upper epiclastic unit, which is developed only to the south of the Petrich fault in the southern part of the Panagyurishte strip. This unit contains intrabasinal clasts from older stratigraphic levels, such as limestones of the Mirkovo Formation, volcanic and epiclastic rocks, indicating basin cannibalism tentatively attributed to basin inversion related to the onset of the shortening.

The uppermost Chugovitsa Formation is represented in this section mainly by muddy turbidites overlying, with a sharp boundary, the upper epiclastic unit (Fig. 8f). Along the section, the turbidites are not thicker than $15 \mathrm{~m}$, whilst north of the Petrich fault they are more than $450 \mathrm{~m}$.

\section{Section Kamenitsa River}

At about $2 \mathrm{~km}$ west of Petrich Village, along the Kamenitsa River, the Upper Cretaceous succession shows some differences compared with the previous section, mainly in its lower part (see Fig. 5). The base of the succession is composed of $60 \mathrm{~m}$-thick pebble to blocky, matrix-supported, red polymict conglomerates, unconformably overlying the Middle Triassic karstified dolostones (Fig. 9a, b). Above them, with a sharp boundary, follows a $\sim 10 \mathrm{~m}$-thick package 

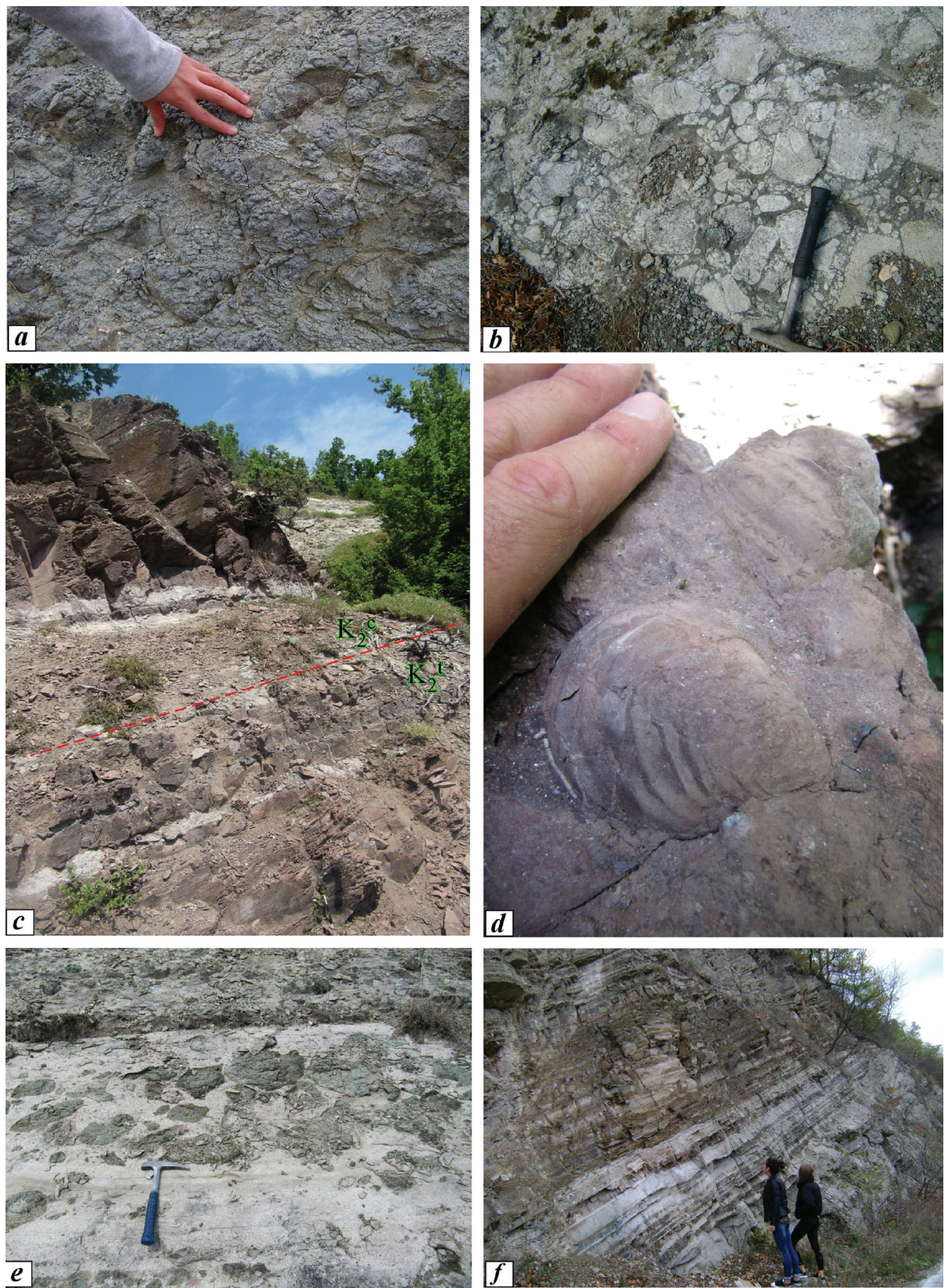

Fig. 7. Field views from section Topolnitsa-South: $a$ ) stratified tuffaceous breccia-conglomerates; $b$ ) hyaloclastites and coherent lava domains; $c$ ) epiclastic turbidites, sandstones and limestones containing the Turonian/Coniacian boundary and deposited on top of the stratified volcanic rocks , (the boundary was drawn by the first occurrence of the inoceramid bivalve Cremnoceramus deformis erectus (Meek, 1876); d) Cremnoceramus deformis erectus (Meek, 1876) collected from the lower part of the lower epiclastic unit; $e$ ) thick lenses of clast- to matrix-supported epiclastic debrites developed on epiclastic turbidites; $f$ ) low-density epiclastic turbidites. 
of medium- to coarse-grained, micaceous, white quartz-dominated sandstones, with a level of abundant shells of bivalves (genus Exogyra) at the base. The randomly observed rip-up clasts of the meta- morphic basement, together with the hummocky cross stratification, indicate reworking by storm waves (proximal tempestites) (Fig. 9c-e). The sandstones are covered by $7-10-\mathrm{m}$ thick grey-greenish
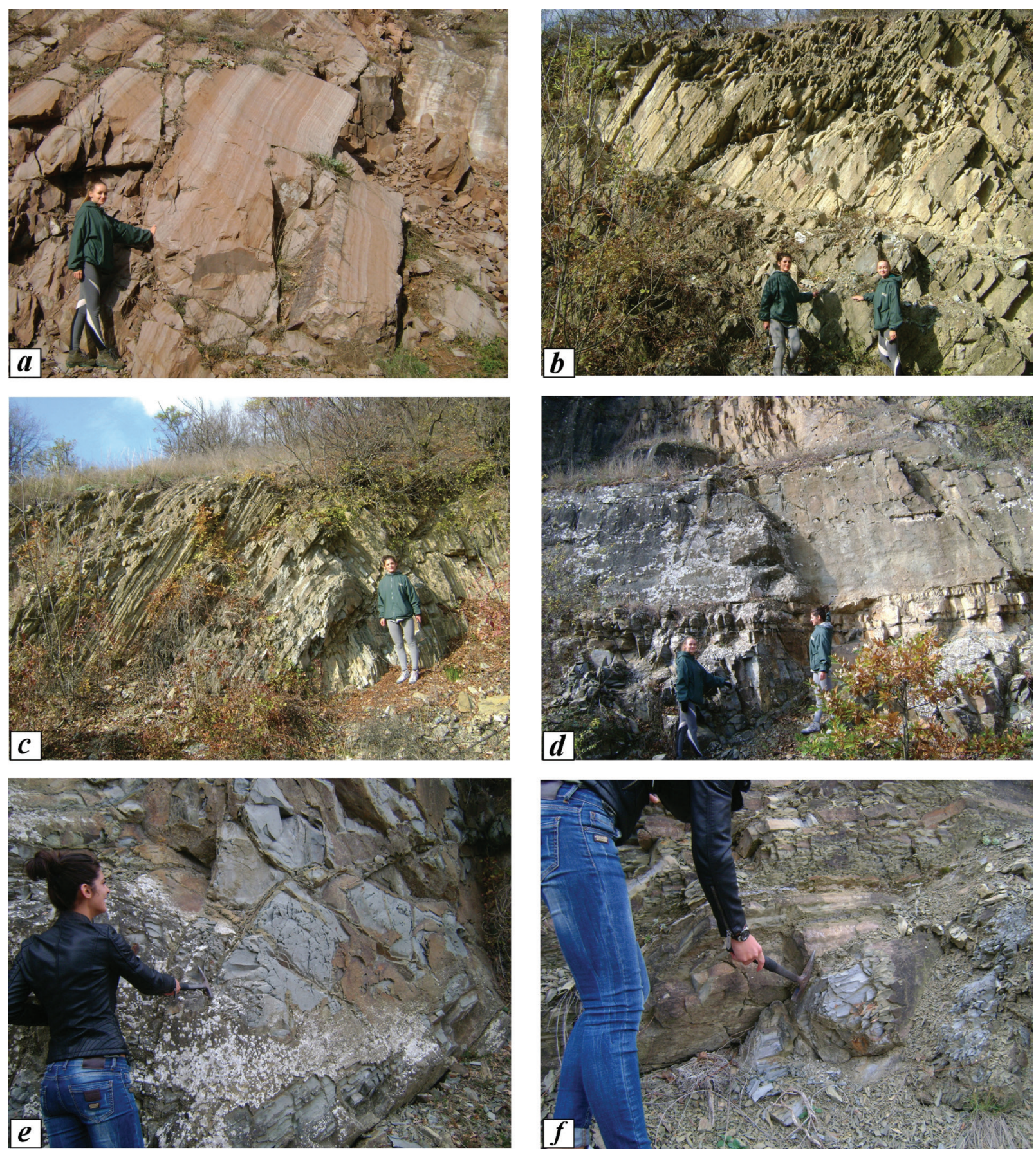

Fig. 8. Field views from section Topolnitsa-South: $a$ ) the limestones of the Mirkovo Formation (red, thick-bedded to massive lowdensity carbonate turbidites) overlie, with a fast transition, the lower epiclastic turbidite unit ; $b$ ) medium- to thick-bedded white carbonate turbidites in the middle part of the Mirkovo Formation and $c$ ) thin-bedded carbonate turbidites in the upper part of the Mirkovo Formation; $d$ ) the upper epiclastic turbidite unit is represented in the lower part by thin- to thick-bedded and massive epiclastic turbidites, containing intrabasinal clasts from volcanic rocks, lower epiclastic turbidites and limestones of the Mirkovo Formation; $e$ ) the upper part of the Mirkovo Formation is composed of bluish thick-bedded to massive epiclastic muddy turbidites; f) the sharp boundary between the upper epiclastic turbidites and the turbidites of the Chugovitsa Formation. 
pebble to cobble clast-supported conglomerates containing clasts from the basement and volcanic rocks (Fig. 9f).

The fourth package is represented by $15-\mathrm{m}$ thick medium- to fine-grained epiclastic, micaceous green sandstones, fining upward (Fig. 10a, b). The siliciclastic sequence is covered, with a fast transition, by whitish limy siltstones with many inoceramid bivalves and ammonites indicating early Coniacian age (Fig. 10c, $d$ ). The inoceramid assemblage
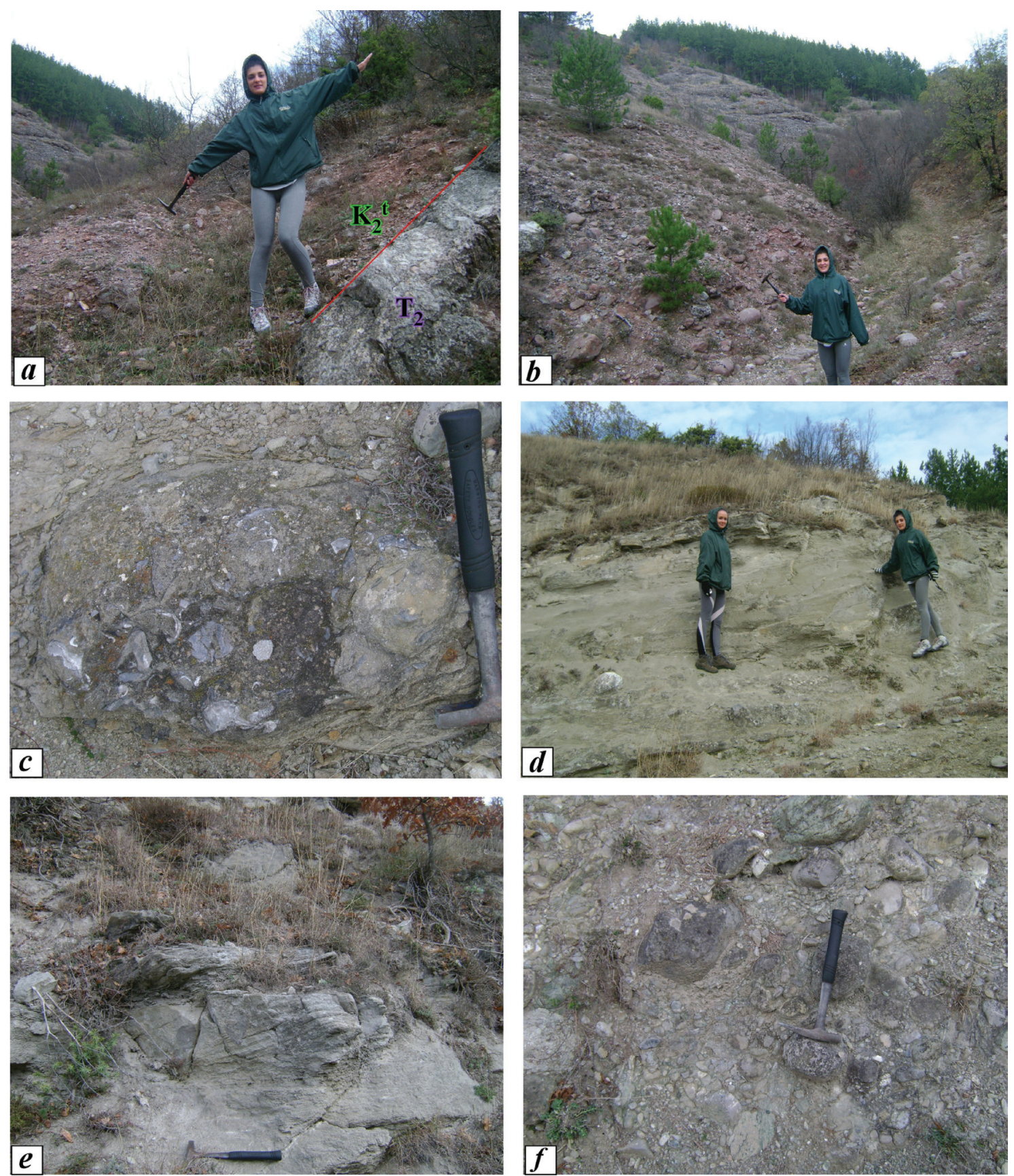

Fig. 9. Field views from section Kamenitsa River: $a$ ) the unconformity between the Middle Triassic dolostones (Iskar Carbonate Group) and the basal terrigenous unit; $b$ ) the lowermost package of the basal terrigenous unit is composed of red thick-bedded to massive, pebble to blocky, clast-supported conglomerates, about $60 \mathrm{~m}$ thick; $c$ ) fossiliferous level of local extinction at the base of package $2 ; d$ ) white quartz-feldspar, micaceous sandstones comprising package 2, the sandstones are poorly consolidated in the lower part of the package, with indications of storm-event deposition (rip-up clasts, hummocky cross stratification); $e$ ) the sandstones are more consolidated in the upper part of package 2, with middle-scale hummocky cross stratification; $f$ ) grey-greenish massive, poorly sorted conglomerates of package 3 , containing volcanic clasts and epiclastic material in the matrix. 

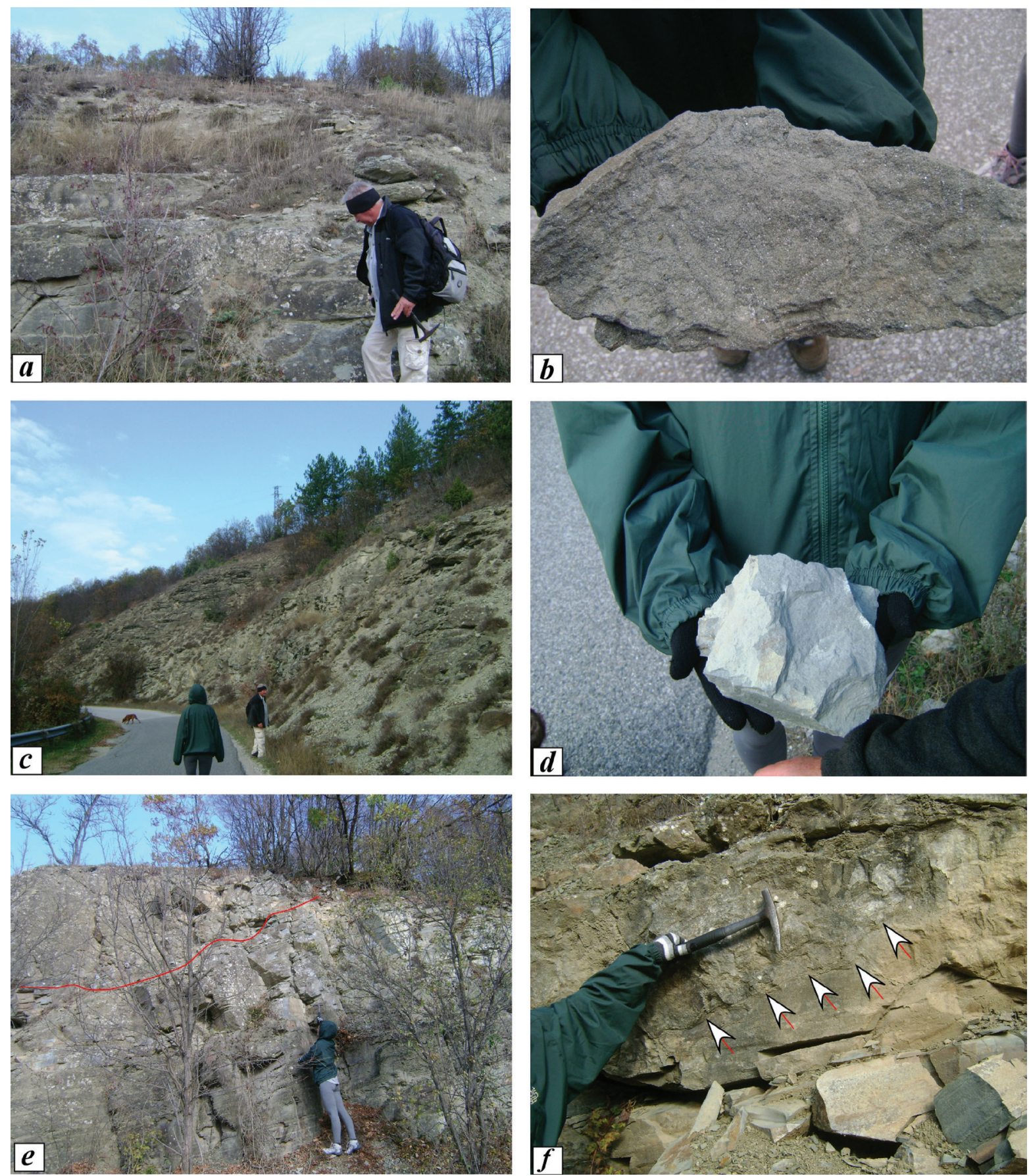

Fig. 10. Field views from section Kamenitsa River: $a, b$ ) package 4 of the basal terrigenous unit, green indistinctly bedded, medium-grained, micaceous epiclastic sandstones; $c, d$ ) the marlstone-limestone unit, containing the Turonian/Coniacian boundary at the base, indicating a change in the deposition; $e, f$ ) the boundary between the marlstone-limestone and lower epiclastic turbidite units indicates again a rapid change in the depositional system because of the incision of matrix-supported epiclastic debrites into the lower unit.

is composed of well-preserved and taxonomically diverse specimens: Mytiloides carpathicus (Simionescu, 1899), Cremnoceramus deformis erectus (Meek, 1876), C. waltersdorfensis hannovrensis (Heinz, 1932), C. websteri (Mantell, 1822) and C. denselamellatus (Kotsyubinsky, 1965). The ammonite fauna includes: Nowakites aff. pailleteanus (d’Orbigny, 1841), Pachydesmoceras cf. pachydiscoides (Matsumoto, 1954), Pseudoxybeloceras matsumotoi (Collignon, 1965) and Neocrioceras 
paderbornense (Schlüter, 1872). Between the last two packages, 0.5-1.5-m thick lenses of epiclastic volcanic debrites, laterally traced for not more than 50-100 m, are observed.

Upward, the sequence is composed of the rocks of the lower epiclastic unit ( 120 m) (Fig. 10e, f), the limestones of the Mirkovo Formation (20-50 m), the upper epiclastic unit (15-20 m) and the sandy turbidites of the Chugovitsa Formation ( 400 m).

\section{Section Topolnitsa-North}

The succession north of the Petrich fault, along the Topolnitsa River, is characterized by lateral interfingering between the units, as well as shortdistance lateral changes in thickness and lithology (Figs 4, 5). At the base of the succession, above the unconformable and irregular contact with the karstified Middle Triassic dolostones, a 2-15-m thick package of micaceous, polylithic, epiclastic, white to brown sandstones crop out. The rip-up clasts from the metamorphic basement (up to $50 \mathrm{~cm}$ in diameter) suggest storm wave influence on the deposition. This part we refer to the basal terrigenous unit.

Upward follows an interval of clast- to matrixsupported epiclastic volcanic debrites (0-15 m-thick), containing clasts from three different magmatic lithologies and traces of hydrothermal activity. The following package (up to 15-m thick) of coarsegrained to gravely sandstones consists of epiclastic grains and one patch reef with bivalve shells at the top. The exposed overlying package of submarine debrite volcaniclastic flow deposits with peperite pinches out in very short distance ( 500 m), from $35 \mathrm{~m}$ to $1 \mathrm{~m}$ toward the northwest, where it interfingers with the lower epiclastic turbidites.

The turbidites of the lower epiclastic unit interfinger with the limestones of the Mirkovo Formation. The Mirkovo Formation is divided into two packages by one wedge of epiclastic sandstones and also contains a layer enriched in epiclastic material at the basal part. The turbidites of the upper epiclastic unit are not observed north of the Petrich fault.

The base of the Chugovitsa Formation is composed of 10-12-m thick intercalation of silty marlstones, marlstones and micrite limestones, very similar to the characteristics of the Voden Member of Moev and Antonov (1978), but $20 \mathrm{~m}$ above the sharp lower boundary another package with the same features and thickness was documented. Unlike their stratotype along the Chugovitsa Valley, the turbidites of the Chugovitsa Formation in this section are very thin- to medium-bedded, indicating relatively deeper-water deposition. They are also rather monotonous, with slightly coarsening-up and thickening-up tendencies, and a total thickness of at least $450 \mathrm{~m}$.

\section{Section Mirkovska River}

This section is followed along the road scarp on the western river bank of the Mirkovska River (Figs 4, 5). Except for the Chugovitsa Formation, the rest of the Upper Cretaceous succession shows significant differences when compared to the nearby sections Kamenitsa and TopolnitsaNorth.

The basal part of the section is composed of more than 100-m thick fine- to coarse-grained sandstones to cobble conglomerates, which can be separated in four packages. The basal package is composed of thick-bedded to massive, coarse-grained sandstones with pebbly layers and rare mudstone seams, coarsening upward and showing features of proximal tempestites (Fig. 11a). The second package consists of irregularly bedded to massive, fine- to coarse-grained yellowish sandstones with big scale synsedimentary slump folds, suggesting a storm dominated deposition (Fig. 11b). The third package is characterized generally by massive, clast- to matrix-supported conglomerates, which are probably a result of a single depositional event, as suggested by the fast lateral and vertical lithologic changes and irregular lower and upper contacts (Fig. 11c, d). The last package is composed of medium- to thickbedded and massive sandstones, coarser and better consolidated than those of the second package, but also representing big scale synsedimentary slump folds (Fig. 11e).

The overlying 10-12-m thick package of epiclastic, matrix- to clast-supported debrites can be correlated with the lower epiclastic debrite package, the upper volcaniclastic unit or the lower epiclastic unit of section Topolnitsa-North. All units composing section Mirkovska River indicate "chaotic" deposition (Fig. 11f), probably related to storm events and/or tectonics, and cannot be traced laterally for a long distance.

The Mirkovo Formation is represented by about 90-m thick, white to red, thick-bedded micrite limestones, indicating shallower deposition and lacking typical turbidite features. The limestones are generally structureless, which is not typical for this unit elsewhere. The Mirkovo Formation is covered by the low-density sandy turbidites of the Chugovitsa Formation, with the same characteristics like those from section Topolnitsa-North, probably because they are situated very close to each other (Fig. 4). 

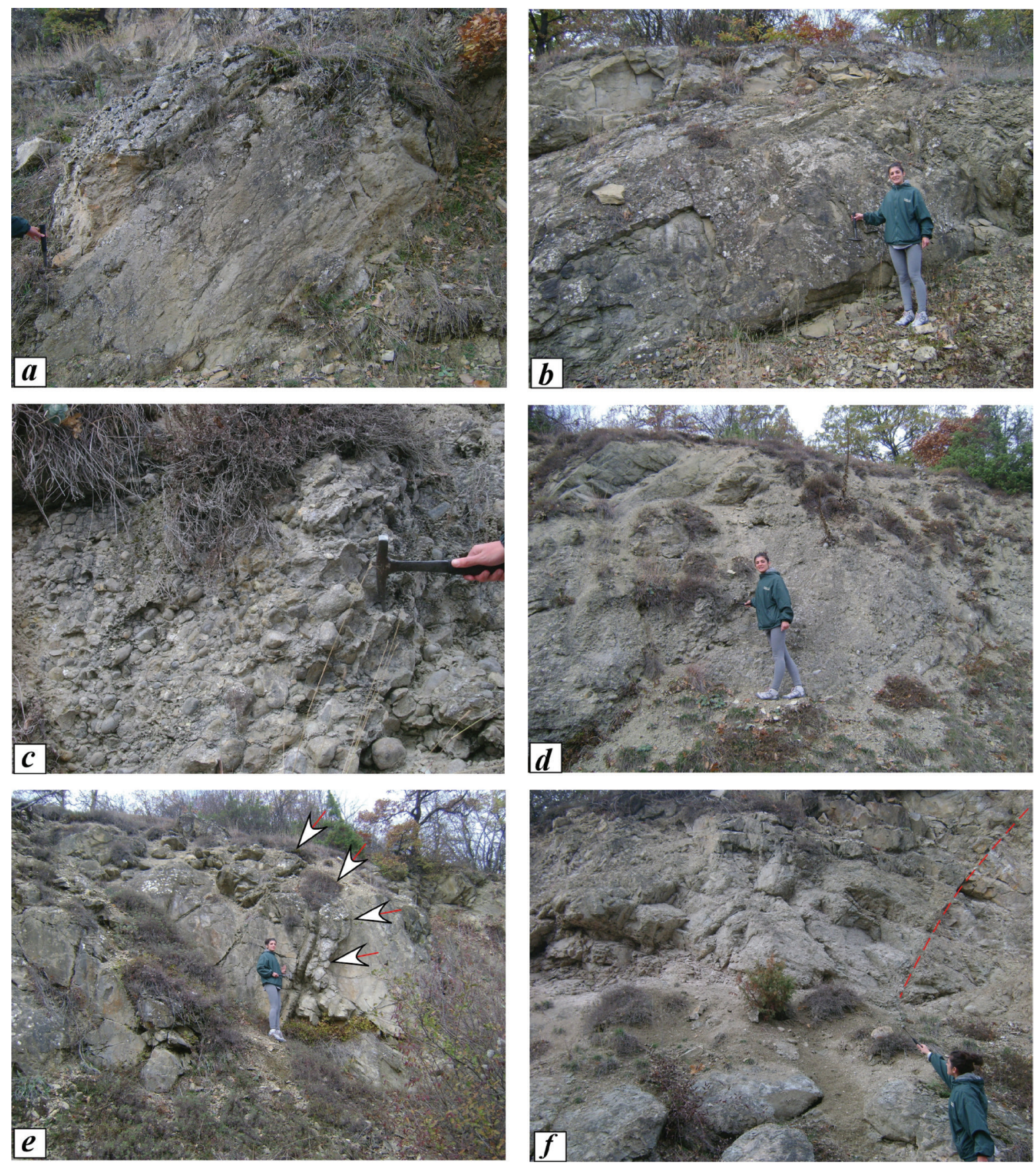

Fig. 11. Field views from the basal terrigenous unit in section Mirkovska River $(a-e)$ : $a)$ thick-bedded to massive, coarse-grained to pebble sandstones with indications of redeposition by storm events (inverse to normal gradation, traction carpets, rip-up clasts); b) massive, fine- to medium-grained yellowish sandstones with big-scale synsedimentary slump folds; $c$ ) massive, poorly-sorted, clast- to matrix-supported conglomerates; $d$ ) massive, medium-grained sandstones with big-scale synsedimentary slump folds and conglomerates, indicating chaotic event deposition; $e$ ) massive medium-grained sandstones with medium-scale synsedimentary slump folds; $f$ ) thick-bedded to massive volcaniclastic package overlying the sandstones.

\section{DISCUSSION}

As a whole, the previous lithostratigraphic scheme for the Upper Cretaceous succession of the Chelopech and Panagyurishte strips is relatively well ap- plicable in a regional scale. However, this scheme is not applicable for small-scale areas. The contradictions stem from the two key assumptions, on which the existing lithostratigraphic scheme was built, namely that all lithostratigraphic units are in 
strict superposition and have the same chronostratigraphic range in all areas of their distributions. The fact that this scheme was established 40 years ago suggests that a revision, including more detailed description of the existing units and further discrimination of sub-units, is more than necessary. Herein, we present an analysis of the problems with the Upper Cretaceous stratigraphy in the region. We put emphasis on the practical approach of the lithostratigraphic scheme and correct description of the units, since the description of lithobodies without tracing their lateral changes in lithology, facies, thickness, age or type of boundaries is not helpful for the practices of field and applied geology.

\section{The lowermost part of the Upper Cretaceous succession}

The basal part of the Upper Cretaceous succession includes various lithologies, which change at short distances, both vertically and laterally, from continental conglomerates to lagoonal and shallowmarine sandstones to relatively deeper-water mudstones and micrite limestones. Only in the area north of Chelopech, the basal part is relatively monotonous (Nikolaev, 1947) and reaches a thickness of $400 \mathrm{~m}$, in which shallow-marine storm influenced sandstone succession is present. Just $5 \mathrm{~km}$ to $7 \mathrm{~km}$ to the west, in the valleys of the Mirkovska and Bunovska rivers, this succession has a contrasting character, with stratified or interbedded sandstones at the base, followed upward by sandstone-mudstone alternation, alternating marlstones and micrite limestones, and micaceous sandstones (Fig. 12).

The basal part of the Upper Cretaceous succession shows even more considerable lateral changes in the Panagyurishte strip, which were well documented in the vicinity of Petrich Village (Figs 4, 5). In the eastern part of the strip, south of the town of Panagyurishte, this interval is missing. The variable lithologies, grading with transitions from terrestrial to marine palaeoenvironments (around Dyulevo, Petrich and Makotsevo villages), suggest deposition in local depocentres and the successions are difficult to correlate, even with the presence of good chronostratigraphic markers, such as the local extinction event, marked by all authors after Mandev (1940) as "abundant fossil content".

The coal-bearing and sandstone units were supposed to be in superposition (Moev and Antonov, 1978), but were in fact not correctly mapped, and the field relations show much more complex stratification in the basal part of the Upper Cretaceous succession. The coals are locally distributed in very thin coal-seams, usually in thick coarse-grained sediments, and cannot be used as a diagnostic characteristic of the unit. However, Vrâbljanski et al. (1961) correctly characterized this part of the sequence as "fore-shore, near-shore clastic horizon".

It should also be emphasized that the basal part of the Upper Cretaceous succession is much more complex than what was previously thought, a fact already noticed by Bončev (1940). These fast changes in lithology, granulometry, thickness and depositional palaeoenvironment in very short distances, showing the lateral interrelations and interfingering at the basal part of the succession, hinder the tracing and mapping of well-defined sub-units. The terrestrial to shallow-marine environment predestined these changes and interrelations of lithologies, which nevertheless must be unified in one single basal terrigenous unit. This part of the succession cannot be validated under one topographic name, due to the varieties in lithology, facies and thickness.

\section{The Upper Cretaceous succession containing magmatic rocks}

The parts of the Upper Cretaceous succession containing magmatic rocks or volcano-sedimentary rocks were subject of numerous investigations and most of these data were summarized by Dabovski et al. (2009) and Popov et al. (2012). In the geological maps (e.g., Iliev and Katskov, 1990; Antonov et al., 2010a), these parts were referred to the Chelopech Formation, a mega unit that includes not only nonlayered volcanic and subvolcanic rocks, but also highly variegated sediments and volcaniclastics that occupy the middle part of the Upper Cretaceous succession (see also Moev and Antonov, 1978). These maps do not represent adequately the existing complexities, e.g., the significant lateral and vertical lithological variations. The current lithostratigraphic model (e.g., Khrischev, 2005; Marti et al., 2018) fail to fit the requirements of contemporary methodology for differentiation of layered vs. non-layered parts of mixed magmatic-sedimentary units. In large scale, the position of the magmatic centres is well known, but no attempts have been made to delineate properly the non-layered and the magmatic parts of the successions away from the volcanos. The stratigraphic schemes that are currently in use also do not take into account the abundance of epiclastic deposits in both the Chelopech and Panagyurishte strips. Our observations indicate that, in a large number of cases, the rocks described as lavabreccia, agglomerate breccia and tuffs are in fact resedimented debris/turbidite flows or other type of epiclastic deposits. Some detailed descriptions 

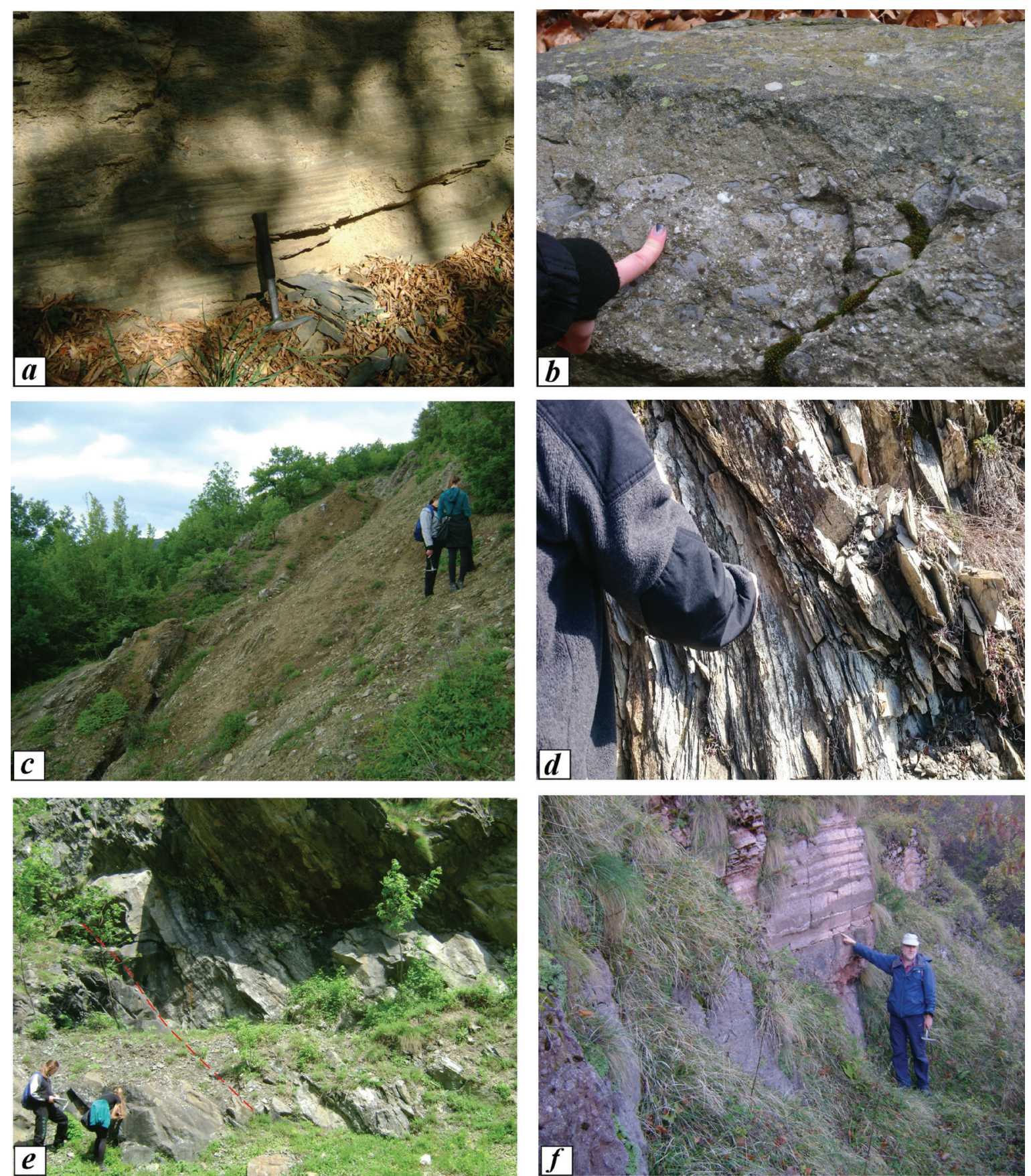

Fig. 12. a) Laminated rhythmic alternation of siltstones and mudstones, indicating lagoonal palaeoenvironment (northern end of the Chelopech strip along the Mirkovska River); $b$ ) matrix-supported conglomerates in the sandstone unit (northern part of the Chelopech unit along the Bunovska River); $c$ ) irregularly alternating mudstones, siltstones, coarse-grained to gravely sandstones below the epiclastic level (southern end of the Chelopech strip, north of Bunovo Railway Station); $d$ ) alternation of marlstones and micrite limestones (southern end of the Chelopech strip, along Mirkovska River); $e$ ) sharp lithological boundary between sandstones and low-density epiclastic turbidites (southern end of the Chelopech strip, along the Bunovska River); $f$ ) transitional boundary between clast- to matrix-supported epiclastic debrites and limestones of the Mirkovo Formation (the Red Rock locality, north of Chelopech Village).

of such type of epiclastic rocks have already been given by Chamberfort and Moritz (2014).

Often, magmatic events are short-lived and, therefore, the related to them volcaniclastic and even epiclastic volcanic rocks are synchronous to the non-layered but stratified volcanic/volcaniclastic rocks. Khrischev (2005) suggested in such cases a different approach in characterizing the magmat- 
ic centres (i.e., non-layered rocks) and related sedimentary/epiclastic/volcaniclastic rocks. In many areas of both the Chelopech and Panagyurishte strips, along the Topolnitsa, Kamenitsa, Mirkovska and Voden rivers, a thick pile of epiclastic volcanic turbidites and debrites is well recognizable, can be delineated at the scale of geologic mapping, and is synchronous with or younger than the magmatic events, which allows these rocks to be separated into mappable units. This has already been commented by Karagyuleva et al. (1974), who described "tuffaceous" and "volcano-sedimentary" units, as well as by Dimitrova et al. (1984), who described a "tuffaceous flysch" unit as interfingering with synchronous volcanic and sedimentary rocks. The presence of epiclastic volcanic material suggests erosion of subaerial magmatic rocks and deposition in both proximal (mainly debrites) and more distal conditions (turbidites), interfingering with synchronous background sediments. One of the best examples of this type of deposition is the so-called two-mica sandstone unit in the eastern part of the Chelopech strip, which interfingers with epiclastic debrites and turbidites, and these features are widely observable (Chamberfort and Moritz, 2014).

There is no sufficient knowledge on the time of the magmatic events. The available geochronological data are just "spot" ages that can hardly provide insights into the period of the magmatic activity and, in most cases, they are not linked with palaeontological data (see Table 1). Only in the work of Reiser et al. (2008), there is an attempt to constrain the period of volcanism, but the poor description of the sample locations and the absence of stratigraphic log do not allow precise calibration of the data to the overall sequence. Nevertheless, the existing geochronological data clearly show that the mag- matic activity is constrained within the Turonian. The significantly younger Campanian age reported by Handler et al. (2004) is hardly comparable to the known palaeontological data from the same area (Karagyuleva et al., 1974).

Our detailed work in Petrich area demonstrated that even locally, the volcanic rocks in the succession can be subdivided into a number of distinct stratigraphic subunits. This is a much needed step that will allow both the vertical and lateral subdivisions of the mega-unit of the Chelopech Formation into separate stratigraphic units.

The subaerial crater of the Vran Kamak volcano and the surrounding area dominated by volcanic rocks can be outlined (even informally) as a volcanic centre, situated to the east of the Topolnitsa River Valley. The stratified volcaniclastic, epiclastic and clastic sedimentary deposits (including volcano bombs), laterally situated to the west of the Topolnitsa River, can be interpreted as synchronous to the volcanic event and distinguished as a member related to the magmatic centre. Conversely, the dominated by epiclastic volcanic turbidites parts of the succession, below the limestones of the Mirkovo Formation, indicate erosion and redeposition of magmatic/volcanic rocks from the volcanic centre, and therefore can be described as a single lithostratigraphic unit.

Many previous authors characterized the boundary between the Chelopech Formation and the overlying Mirkovo Formation as erosional (Moev and Antonov, 1978; Iliev and Katskov, 1990; Cheshitev et al., 1995; Popov, 2005; Dabovski et al., 2009; Antonov et al., 2010a, b). However, our observations show that the boundary is transitional and it is drawn between the epiclastic volcanics and the carbonate turbidites, which excludes any possibility of erosion between them (Fig. 12f).

Table 1

Geochronological and palaeontological data for the magmatic centres

\begin{tabular}{ccc}
\hline Magmatic center & Age & Source \\
\hline Elatsite & $91.48-91.10 \mathrm{Ma}$ & von Quadt et al. (2002) \\
Chelopech & $92.22 \mathrm{Ma}$; $91.30 \mathrm{Ma}$ & U-Pb, Moritz et al. (2003) \\
& $92.47 \pm 0.15-91.30 \pm 0.3 \mathrm{Ma}$ & Chamberfort et al. (2004) \\
& & Stoykov et al. (2004) \\
& & Handler et al. (2004) \\
Asarel & $90.06 \pm 0.23 \mathrm{Ma}$ & von Quadt et al. (2005) \\
& & Nedyalkov et al. (2007) \\
Golyama Rakovitsa & $89.47 \pm 1.2 \mathrm{Ma}$ & Nedkova et al. (2012) \\
Vran Kamak & Turonian/Coniacian boundary & Palaeontological data \\
\hline
\end{tabular}




\section{The uppermost part of the Upper Cretaceous succession}

There is a general agreement that the uppermost part of the Upper Cretaceous succession displays consistent features in terms of spatial distribution of their comprising units and their lithological content. This consistence allows them to be used as "markers" in outlining the main fold structures. The con- cept of "layer cake" stratigraphy for this part (e.g., Karagyuleva et al., 1974, fig. 3; Dabovski et al., 2009) devoid of large-scale lateral variations has been widely accepted. After the work of Moev and Antonov (1978), all researchers recognize in this part of the succession the Mirkovo and Chugovitsa formations. However, our studies indicate some differences with this model. First, the Mirkovo Formation shows significant lateral variations in facies,
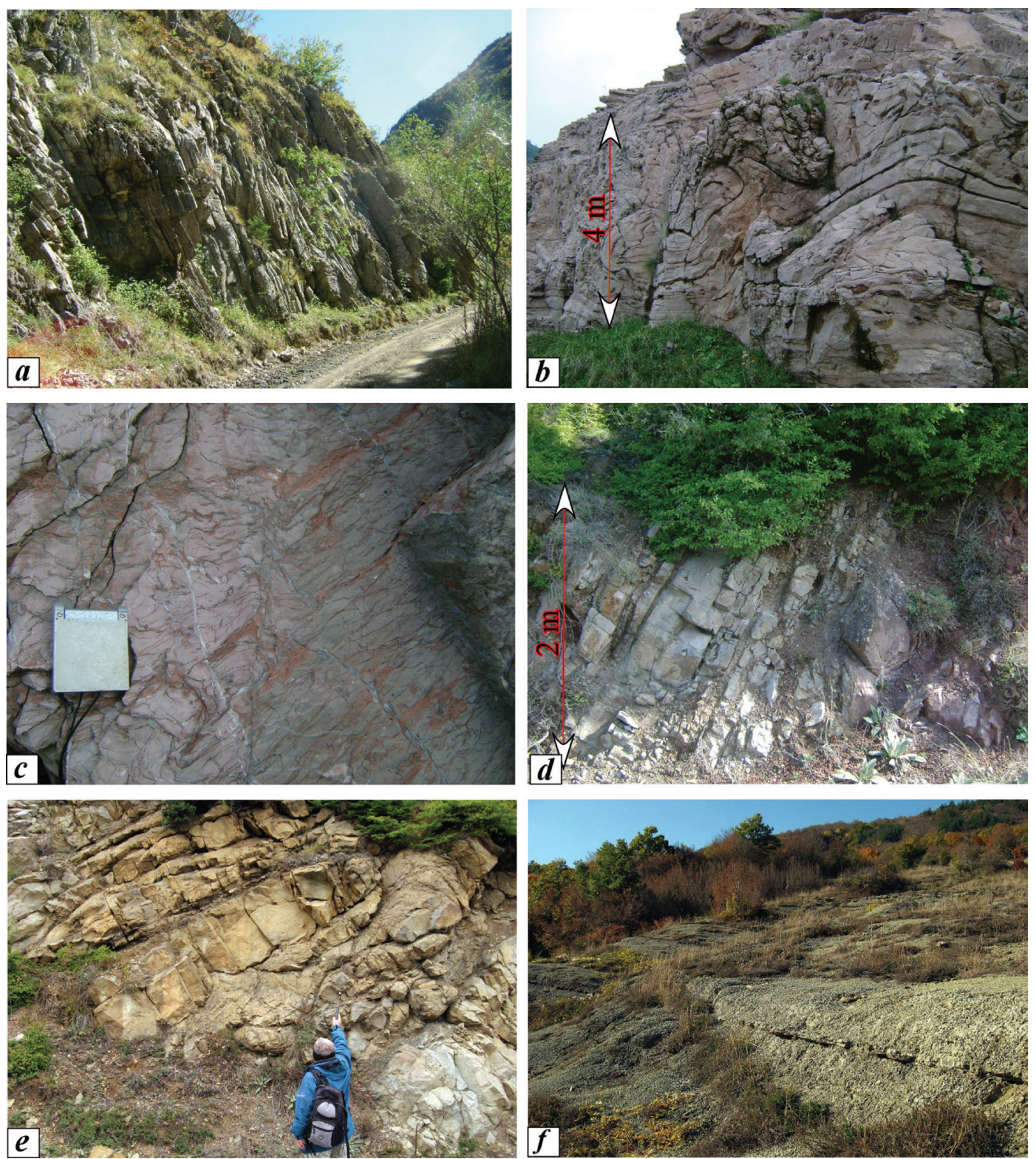

Fig. 13. a) The limestones of the Mirkovo Formation, along the Mirkovska River, showing features of low-density carbonate turbidites; $b$ ) shallower palaeoenvironment in the Mirkovo Formation with big-scale synsedimentary slump folds and centimetre-scale clasts from the high-grade metamorphic basement at the Red Rock locality north of Chelopech Village; $c$ ) small-scale slump folds in the Mirkovo Formation along the Chugovitsa Valley; $d$ ) the basal part of the Chugovitsa Formation in the Chugovitsa Valley, north of Chelopech Village, composed of low-density sandy turbidites that contain $\sim 50 \%$ of epiclastic material; $e$ ) big-scale synsedimentary slump folds in the upper part of the Chugovitsa Formation along the Chugovitsa Valley; $f$ ) the topmost parts of the Chugovitsa Formation are composed of a 25-30-m thick package of marlstones with rare sandstone beds. 
thickness and colour, and indicates a deposition from the basin floor to shallow-water conditions (see Fig. $13 a-c$ ). The age is also variable, from the Coniacian to the early Campanian, in the westernmost part of the Panagyurishte strip (Dimitrova et al., 1984; Sinnyovsky, 2005) to early Campanian near the Kamenitsa River Valley (Dimitrova et al., 1984). The thickness of the Mirkovo Formation varies from $480 \mathrm{~m}$ in the westernmost part of the Panagyurishte strip to less than $1 \mathrm{~m}$ west of Chelopech Village in the Chelopech strip, where it corresponds to a single bed within the sandy turbidites of the Chugovitsa Formation (Fig. 13g). South of the town of Strelcha and east of Dyulevo Village, in the Panagyurishte strip, the limestones of the Mirkovo Formation interfinger with the volcaniclastic and the epiclastic rocks, and constitutes at least three limestone levels.

Although the uppermost part of the Chugovitsa Formation is generally built of siliciclastic turbidite deposits, there are some important lateral variations. As is the case with other units nominated by Moev and Antonov (1978), this problem arises from the lack of a properly described stratotype. In the type-area for the Chugovitsa Formation, this unit is represented by different lithologies and facies, including "classical" low-density sandy and epiclastic turbidites, amalgamated high-density sandy turbidites with large-scale synsedimentary slump folds, and muddy turbidites (Fig. 13d-f). Along the northern limb of the Chelopech syncline, the rocks of the Chugovitsa Formation are associated with shallower depositional palaeoenvironment, with missing turbiditic structures and ichnofossils. Along the Voden River Valley, in the Chelopech strip, the Chugovitsa Formation is represented by thick-bedded, amalgamated high-density sandy turbidites, typical for proximal parts of the depositional system, whilst north of the Petrich fault, in the Panagyurishte strip, the turbiditic succession is clearly distal. The Voden Member of the Chugovitsa Formation is intensively tectonized in its type-area and needs precise interpretation from environmental viewpoint. To the north of Petrich Village, at least two levels with characteristics similar to the Voden Member have been established at the lower part of the Chugovitsa Formation.

The turbidites of the Chugovitsa Formation generally overlie the silty mudstones of the Voden Member, the limestones of the Mirkovo Formation, or directly lie on the epiclastic volcanic debrites west of Chelopech Village (Fig. 13h). South of the Petrich fault, along the Topolnitsa and Ka- menitsa rivers, a package of epiclastic turbidites and debrites, containing clasts of older intrabasinal rocks, have been documented between the Mirkovo and Chugovitsa formations. The fact that the Upper Cretaceous succession ends with turbidites is generally odd for the evolution of the basin system and probably suggests very fast basin inversion.

\section{CONCLUSIONS}

The lowermost part of the Upper Cretaceous succession shows significant lateral variations in terms of thickness, lithology, facies and colour. We designate this part as basal terrigenous unit.

The middle parts of the succession contain abundant volcanic, volcaniclastic and epiclastic volcanic rocks. Here, we can distinguish non-stratified units, represented by volcanic centres (Vran Kamak, Chelopech, Smolsko, Golyama Rakovitsa, etc.), and layered units, built up of epiclastic volcanic rocks and various clastic sediments. Furthermore, the epiclastic rocks can be separated into proximal (locally developed and synchronous to the magmatism) and distal sub-units. For the time being, this subdivision has been applied to relatively limited areas.

Our data clearly indicate that the previously applied model is invalid. While recognizing the general progression from limestone-marl sedimentation to turbiditic-siliciclastic one, the lateral differences in thickness and lithology within the Mirkovo Formation, as well as its lateral interfingering with epiclastic volcanic levels, clearly point out that the lithological log of the uppermost part is much more complicated than what was previously thought. South of the Petrich fault, the succession is further complicated by the presence of an upper epiclastic unit, usually sandwiched between the Mirkovo and Chugovitsa formations. Despite the established lateral differences, there are lithologic similarities in some chronostratigraphic intervals, which argue for the existence, at a certain stage of its evolution in the Late Cretaceous, of a single basin or a connected basinal system, later disrupted by Late Alpine tectonics and post-Eocene extension.

\section{Acknowledgements}

The study was partly supported by the Sofia University Fund “Scientific Researches” (grants nos. 153/2016, 207/2017, 11/2018 and 177/2019). We wish to thank two anonymous reviewers for their much-appreciated critical reviews and suggestions. 


\section{REFERENCES}

Andert, H. 1911. Die Inoceramen des Kreibitz-Zittauer Sandsteingebirges. Festschrift des Humboldtvereins zur Feier des 50 jährigen Bestehens am 22 Oktober 1911, Humboldt-Verein, Ebersbach, 33-64.

Antonov, M., Gerdjikov, S. Metodiev, L., Kiselinov, H., Sirakov, V., Valev, V. 2010a. Explanatory note to the Geological Map of the Republic of Bulgaria in Scale 1:50 000, Pirdop map sheet. Ministry of Environment and Water, Bulgarian National Geological Survey, Sofia, 39-47 (in Bulgarian).

Antonov, M., Gerdjikov, S. Metodiev, L., Kiselinov, H., Sirakov, V., Valev, V. 2010b. Explanatory note to the Geological Map of the Republic of Bulgaria in Scale 1:50 000, Etropole SW map sheet. Ministry of Environment and Water, Bulgarian National Geological Survey, Sofia, 46-56 (in Bulgarian).

Bončev, E. 1940. Über die Geologie des Bajlovo Teiles der Panagjurishte-Zone der Srednogorie unter Berücksichtigung der Tektonik dieser Zone. Review of the Bulgarian Geological Society 11, 205-238 (in Bulgarian, with German abstract).

Chamberfort, I., Moritz, R. 2014. Subaqueous environment and volcanic evolution of the Late Cretaceous Chelopech epithermal Au-Cu deposit, Bulgaria. Journal of Volcanology and Geothermal Research 289, 1-13.

Chamberfort, I., von Quadt, A., Moritz, R. 2004. Volcanic environment and geochronology of the Chelopech high-sulfidation epithermal deposit, Bulgaria: regional relationship with associated deposits. Geophysical research, Abstracts, 5, 00569 (CD version)

Cheshitev, G., Milanova, V., Sapunov, I., Tchoumatchenko, P. 1995. Explanatory note to the Geological Map of the Republic of Bulgaria in scale 1:100 000, Teteven map sheet. Geological Institute, Bulgarian Academy of Sciences and “Geology and geophysics” Ltd, 94 pp. (in Bulgarian).

Collignon, M. 1965. Atlas des fossiles caractéristiques de Madagascar (Ammonites), Fascicule XIII (Coniacien). Annuaire de la Service Géologique de Madagascar, 514-606.

Dabovski, H., Kamenov, B., Sinnyovsky, D., Vassilev, E., Dimitrova, E., Bairaktarov, I. 2009. Upper Cretaceous geology. In: Zagorchev, I., Dabovski, Ch., Nikolov, T. (Eds), Geology of Bulgaria, Volume II, Part 5: Mesozoic geology. "Prof. Marin Drinov" Academic Publishing House, Sofia, p. 355 (in Bulgarian).

Dimitrov, C. 1936. Die westliche Verbindung zwischen Balkan und Sredna-gora. Annual of Sofia University "St Kliment Ohridski", Faculty of Physics and Mathematics 32 (3), 175-208 (in Bulgarian, with German abstract).

Dimitrova, E., Nachev, I., Slavov, S. 1984. Upper Cretaceous stratigraphy of the Panagyurishte area. Bulletin of the Geological Institute, Bulgarian Academy of Sciences, Series Paleontology, Stratigraphy, Lithology 19, 65-83 (in Bulgarian).

d’Orbigny, A. 1841. Paléontologie française: Terrains crétacés. I, Céphalopodes. Masson, Paris, 121-430.

Dotseva, Z., Vangelov, D., Gerdzhikov, I., Dancheva, D. 2016. Bunovo-Anton Fault Zone -an array of fault segments or remnants of a Late Alpine fault zone?. Bulgarian Geological Society, National Conference with International Participation “Geosciences 2016”, Abstracts, 87-88.

Handler, R., Neubauer, F., Velichkova, S., Ivanov, Z. 2004. ${ }^{40} \mathrm{Ar} /{ }^{39} \mathrm{Ar}$ age constraints on the timing of magmatism in the Panagyurishte region, Bulgaria. Schweizerische Mineralogische und Petrographische Mitteilungen 84 (1), 119-132.
Heinz, R. 1932. Aus der neuen Systematik der Inoceramen (Inoceramen XIV). Mitteilungen aus dem mineralogischgeologischen Staatsinstitut in Hamburg 13, 1-26.

Gallhofer, D., Quadt, A., Peytcheva, I., Schmid, S., Heinrich, A.C. 2015. Tectonic, magmatic and metallogenic evolution of the Late Cretaceous Arc in the Carpathian-Balkan orogen. Tectonics 34, 1813-1836.

Georgiev, S., Velev, S., Vangelov, D., Balkanska, E. 2013. Volcanic activity and sedimentary gravity flow triggering: a case study from the Upper Cretaceous Vran Kamik paleovolcano, Central Srednogorie. Bulgarian Geological Society, National Conference with International Participation "Geosciences 2013”, Abstracts, 25-26.

Goldfuss, A. 1836. Petrefacta Germaniae - Abbildungen und Beschreibungen der Petrefakten Deutschlands und der angrenzenden; II. Teil. Arnz and Co., Düsseldorf, 312 pp.

Iliev, K., Katskov, N. 1990. Geological Map of the People's Republic of Bulgaria in scale 1:100 000, Panagyurishte map sheet. Committee of Geology, Sofia (in Bulgarian).

Ivanov, Ž. 1998. Tectonics of Bulgaria. Professorship thesis, Sofia University “St Kliment Ohridski”, 579 pp. (in Bulgarian, unpublished).

Ivanov, Ž. 2017. Tectonics of Bulgaria. Sofia University Press, Sofia, 331 pp. (in Bulgarian).

Karagyuleva, J., Kostadinov, V., Tsankov, T., Gochev, P. 1974. Composition of the Pangyuriste strip east of the Topolnitsa River. Bulletin of the Geological Institute, Bulgarian Academy of Sciences, Series Geotectonics 23, 231-301 (in Bulgarian).

Knaak, M., Márton, I., Tosdal, R. M., van der Toorn, J., Davidovic, D., Strmbanovic, I., Zdravkovic, M., Živanovic, M., Hasson, S. 2016. Geologic setting and tectonic evolution of porphyry $\mathrm{Cu}-\mathrm{Au}$, polymetallic replacement, and sedimentary rock-hosted Au deposits in the northwestern area of the Timok Magmatic Complex, Serbia. Society of Economic Geologists, Special Publication 19, 1-28.

Kounov, A., Gerdjikov, I., Vangelov, D., Balkanska, E., Lazarova, A., Georgiev, S., Stockli, D., Blunt, E. 2017. First thermochronological constraints on the Cenozoic extension along the Balkan Fold-Thrust Belt (Central Stara Planina Mountain, Bulgaria). International Journal of Earth Sciences 107 (4), 1515-1535.

Kotsubinsky, S.P. 1965. A new species of Inoceramus from the Upper Turonian of the Volyn - Podolian Plateau. Palaeontogical Journal 2, 48-50.

Khrischev, K. 2005. Lithostratigraphy and mapping of units of metamorphic, mixed and volcanic rocks (a discussion). Review of the Bulgarian Geological Society 66 (1-3), 127142 (in Bulgarian).

Mandev, P. 1940. Geologische Skizze des Gebietes westlich von Topolnica zwischen den Dörfern, Poibrene, Petrič, Benkowski und Kamenica. Review of the Bulgarian Geological Society 11, 169-180 (in Bulgarian, with German abstract).

Mantell, G. 1822. Fossils of the South Downs; or illustrations of the geology of Sussex. R. Relfe, London., 320 pp.

Martí, J., Groppelli, G., Brum da Silveira, A. 2018. Volcanic Stratigraphy: A Review. Journal of Volcanology and Geothermal Research 357, 68-91.

Marwick, J. 1926. Tertiary and recent Volutidae of New Zealand. Transactions of the New Zealand Institute 56, 259303.

Matsumoto, T. 1954. Family Puzosiidae from Hokkaido and Saghalien (Studies on Cretaceous Ammonoidea from Hok- 
kaido and Saghalien - V). Memoirs of the Faculty of Science, Kyushu University, Series D, Geology 5 (2), 69-118.

Meek, F.B. 1876. A report on the invertebrate Cretaceous and Tertiary fossils of the upper Missouri country, 1876. Invertebrate Paleontology 9, 1-629.

Moev, M., Antonov, M. 1978. Stratigraphy of the Upper Cretaceous in the eastern part of the Sturguel-Tchelopech strip. Annual of the University of Mining and Geology, Faculty of Geology and Geophysics 28 (2), 7-30 (in Bulgarian, with English abstract).

Moritz, R., Jacquat, S., Chambefort, I., Fontignie, D., Petrunov, R., Georgieva, S., von Quadt, A. 2003. Controls of ore formation at the high-sulphidation $\mathrm{Au}-\mathrm{Cu}$ Chelopech deposit, Bulgaria: evidence from infrared fluid inclusion microthermometry of enargite and isotope systematics of barite. In: Eliopoulos, D.G. (Eds), Mineral Exploration and Sustainable Development. Millpress, Rotterdam, 1209-1212.

Nedkova, K., Petrov, N., Peytcheva, I. 2012. Age of the porphyritic intrusions from Golyama Rakovitsa ore occurrence. Bulgarian Geological Society, National Conference with International Participation "Geosciences 2012”, Abstracts, 6162 (in Bulgarian).

Nedyalkov, R., Zartova, A., Moritz, R. 2007. Magmatic rocks and evolution of the Late Cretaceous magmatism in the region of the Assarel porphyry copper deposit, Central Srednogorie. Review of the Bulgarian Geological Society 68 (1-3), 57-76.

Nikolaev, G. 1947. Contribution à l'étude géologique du versant méridional du Balkan entre les passes de Botevgrade et de Zlatitza. Review of the Bulgarian Geological Society 15-19 (1), 1-18 (in Bulgarian, with French abstract).

Popov, K. 2005. Lithostratigraphy of the Late Cretaceous rocks in the Panagyurishte Ore Region. Annual of the University of Mining and Geology, Faculty Geology and Geophysics 48 (1), 101-114.

Popov, P., Strashimirov, S., Popov, K., Kanazirski, M., Bogdanov, K., Radichev, R., Dimovski, S., Stoykov, S. 2012. In: Geology and metallogeny of the Panagyurishte ore region (Extended Resume). University of Mining and Geology "St. Ivan Rilski” Press, Sofia, 191-227.

Rieser, B.A., Neubauer, F., Handler, R., Velichkova, S., Ivanov, Z. 2008. New ${ }^{40} \mathrm{Ar} /{ }^{39} \mathrm{Ar}$ age constraints on the timing of magmatic events in the Panagyurishte region, Bulgaria. Swiss Journal of Geosciences 101, 107-123.

Schlüter, C. 1872. Cephalopoden der oberen deutschen Kreide. Palaeontographica 21, 1-120.

Stoykov, S., Peytcheva, I., von Quadt, A., Moritz, R., Frank, M., Fontignie, D. 2004. Timing and magma evolution of the Chelopech volcano, Bulgaria. In: Von Quadt, A, Driesner, T., Heinrich, C.A. (Eds), Special Volume "Geodynamics and Ore Deposit Evolution in the Alpine-Balkan-Carpathian belt". Swiss Bulletin of Mineralogy and Petrology 84 (1/2), 101-118.

Simionescu. J. 1899. Fauna cretacică supérioră de la Ürmös (Transilvania). Publicaţiunile Fondului Vasilie Adamache 4, 238-274.
Sinnyovsky, D. 2005. Campanian nannofossil zones in the Mediterranean Upper Cretaceous in Sofia Balkan between Buhovo, Jelyava and Eleshnitsa. Annual of the University of Mining and Geology 48 (1), 123-128.

Tzankov, Tz. 1961. Notizen Über die Tektonik des Gebietes von Galabec und der angrenzenden Teile. Travaux sur la Géologie de Bulgarie, Stratigraphie et Tectonique 2, 183202 (in Bulgarian, with German abstract).

Velichkova, S., Handler, R., Neubauer, F., Ivanov, Ž. 2004. Variscan to Alpine tectonothermal evolution of the Central Srednogorie unit, Bulgaria: constraints from ${ }^{40} \mathrm{Ar} /{ }^{39} \mathrm{Ar}$ analysis. Schweizerische Mineralogische und Petrographische Mitteilungen 84, 133-151.

von Quadt, A., Moritz, R., Peytcheva, I., Heinrich, Ch. A. 2005. Geochronology and geodynamics of Late Cretaceous magmatism and $\mathrm{Cu}-\mathrm{Au}$ mineralization in the Panagyurishte region of the Apuseni-Banat-Timok-Srednogorie belt, Bulgaria. Ore Geology Reviews 27, 95-126.

von Quadt A., Peytcheva I., Kamenov B., Fanger L., Heinrich C.A., Frank M. 2002. The Elatsite porphyry copper deposit in the Panagyurishte ore district, Srednogorie zone, Bulgaria: $\mathrm{U}-\mathrm{Pb}$ zircon geochronology and isotope-geochemical investigations of magmatism and ore genesis. In: Blundell, D.J., Neubauer, F., von Quadt, A. (Eds), The Timing and Location of Major Ore Deposits in an Evolving Orogen. Geological Society London, Special Publications 204, 119-135.

Vrâbljanski, B., Budurov, K., Tzankov, Tz. 1961. Beitrag zur Stratigraphie der Oberkreide zwischen dem Sofia Becken und der Stadt Panagjurište. Annuaire de la Direction pour les recherches géologiques et minières en Bulgarie 11, 117-132 (in Bulgarian, with German abstract).

Walaszczyk, I. 1992. Turonian through Santonian deposits of the Central Polish Uplands; their facies development, inoceramid paleontology and stratigraphy. Acta Geologica Polonica 42, 1-122.

Walaszczyk, I., Wood, C.J., Lees, J.A., Peryt, D., Voigt, S., Wiese, F. 2010. The Salzgitter-Salder Quarry (Lower Saxony, Germany) and Słupia Nadbrzeżna river section (Central Poland): a proposed candidate composite Global Boundary Stratotype Section and Point for the Coniacian Stage (Upper Cretaceous). Acta Geologica Polonica 60 (4), 445-477.

Wang, C.S., Hu, X.M., Huang, Y.J., Scott, R.W., Wagreich, M. 2009. Overview of Cretaceous Oceanic Red Beds (CORBs): a window on global oceanic and climate change. In: Hu, X.M., Wang, C.S., Scott, R.W., Wagreich, M., Jansa, L. (Eds), Cretaceous Oceanic Red Beds: Stratigraphy, Composition, Origins and Paleoceanographic and Paleoclimatic Significance. SEPM Special Publication 91, 13-33.

Zagorchev, I., Pavlishina, P., Cernjavska, S., Boyanov, I., Goranov, A. 2001. First data on a Danian age of the Conglomeratic Formation near Panagyurishte and Strelcha (Sredna-Gora Mountains). Comptes rendus de l'Académie bulgare des Sciences 54 (8), 53-56. 